\title{
2. SITE 371: SOUTH BALEARIC BASIN
}

\author{
Shipboard Scientific Party ${ }^{1}$
}

\section{SITE DATA}

Position: $37^{\circ} 35.8^{\prime} \mathrm{N}, 05^{\circ} 14.55^{\prime} \mathrm{E}$

Water Depth (sea level): 2792 corrected meters, echo sounding

Bottom Felt at: 2826 meters, drill pipe

Penetration: 55.1 meters

Number of Holes: 1

Number of Cores: 8

Total Core Recovered: 43.3 meters

Percentage Core Recovery: $70.0 \%$

Oldest Sediment Cored:

Depth subbottom: 551 meters

Nature: Dolomitic mudstone

Age: Late Miocene

Basement: Not reached

Principal Results: The primary objective was to obtain samples on the flank of a positive structural feature in the South Balearic Basin. Unfortunately, a thin veneer of evaporite was present above basement, and the hole was terminated in accordance with a ruling of the JOIDES Safety Panel. Two major stratigraphic units were penetrated: a Plio-Quaternary sequence of calcareous muds and mudstones with sandy intercalations overlies the late Miocene evaporites (Figure 1). The muds and mudstones appear to have been deposited on a knoll which has stood slightly above the surrounding abyssal plain since the early Pliocene. The intercalated sands are distal turbidites and deposits reworked by contour currents. The depositional environment has remained in at least the upper to mid-mesobathyal (1000-2500 $\mathrm{m})$ depth range from the early Pliocene to Holocene. The lowest Pliocene is absent on the paleotopographic high. The Messinian probably includes a sand deposit at its top, which is underlain by nodular anhydrite, containing stromotilitic seams and dolomitic sandy mud. This upper Miocene sequence is interpreted as indicative of a subaerial to shallow

${ }^{1}$ Kenneth J. Hsü (Co-chief scientist), Eidg. Technisches Hochschule, Geologisches Institut, Zurich, Switzerland; Lucien Montadert (Co-chief scientist), Division Geologie, Institut Francais du Petrole, Rueil Malmaison, France; Daniel Bernoulli, Geologisch-palaontologisches Institut der Universitat Basel, Basel, Switzerland; Germaine Bizon, Bureau d'Etudes Industrielles et de Cooperation de l'Institut Francais du Petrole, Rueil Malmaison, France; Maria Cita, Instituto di Geologia, Universita degli Studi di Milano, Milano, Italy; Al Erickson, Department of Geology, University of Georgia, Athens, Georgia; Frank Fabricius, Institut fur Geologie Techn. Universitat, Munich, Germany; Robert E. Garrison, University of California, Santa Cruz, California; Robert B. Kidd, Institute of Oceanographic Sciences, Wormley, United Kingdom; Frederic Mélières, Laboratoire de Geologie Dynamique, University of Paris, Paris, France; Carla Müller, Geologisch-Paleontologisches Instutut der Johann Wolfgang Geothe-Universitat, Frankfurt, Germany (Present address: Bureau d'Etudes Industrielles et de Cooperation de L'Institut Francais du Petrole, Rueil Malmaison, France); Ramil C. Wright, Beloit College, Department of Geology, Beloit, Wisconsin (Present address: Department of Geology, The Florida State University, Tallahassee, Florida. subaqueous evaporitic environment analogous to presentday salt pans.

\section{BACKGROUND AND OBJECTIVES}

Prior to our drilling, extensive geophysical surveying, including multichannel seismic reflection profiling, made it possible to establish the main structural features and seismic stratigraphy of the Balearic Basin. Broadly, two major subbasins can be distinguished. Their sediment infills seem similar despite their somewhat different geological framework.

1) The Algero-Provençal Basin extends north-south from the southern French coast to Algeria. It is bounded on the east by the Corsica-Sardinia Margin and on the west by a Gulf of Valencia Margin, the East Balearic Margin, and the South Menorcan Marginal Plateau (Figure 2).

2) The South Balearic Basin extending east-west has the same depth, but is structurally separated by the South Menorcan Plateau which extends toward the south coming close to the Algerian Margin.

In both basins the sedimentary section as recorded on seismic profiles can be subdivided into three main units (Mauffret et al., 1973):

Seismic Unit 1: A Pliocene-Quaternary sequence whose thickness varies from some hundred meters to 1500 meters. It is composed mainly of hemipelagic mud with turbidite or contourite interbeds. Interval velocities range from $1.6 \mathrm{~km} / \mathrm{sec}$ to $2.8 \mathrm{~km} / \mathrm{sec}$.

Seismic Unit 2: An evaporitic sequence split into two subunits: (a) an upper evaporitic unit made up of an alternation of marls, dolomite, anhydrite, gypsum, and some halite. The mean interval velocity is about 3.5 $\mathrm{km} / \mathrm{sec}$, and the thickness can be as great as 600 meters. (b) a salt unit which is the source-bed of the Balearic salt diapirs. Its velocity is about $4.5 \mathrm{~km} / \mathrm{sec}$, and it can attain thicknesses of 1000 meters or more.

Below the salt layer other evaporite layers may be present. During DSDP Leg 13, the top of seismic Subunit 2a was drilled. This drilling established a Messinian age for these evaporites.

Seismic Unit 3: A pre-evaporitic sequence whose thickness could reach 3000 to 6000 meters. Its age is probably Miocene, although it might be as old as Oligocene in some areas.

Comparing the Algero-Provençal Basin with the South Balearic Basin, it appears that the sedimentary series is generally thinner in the latter and there the acoustic basement of the basin can be determined in places. 

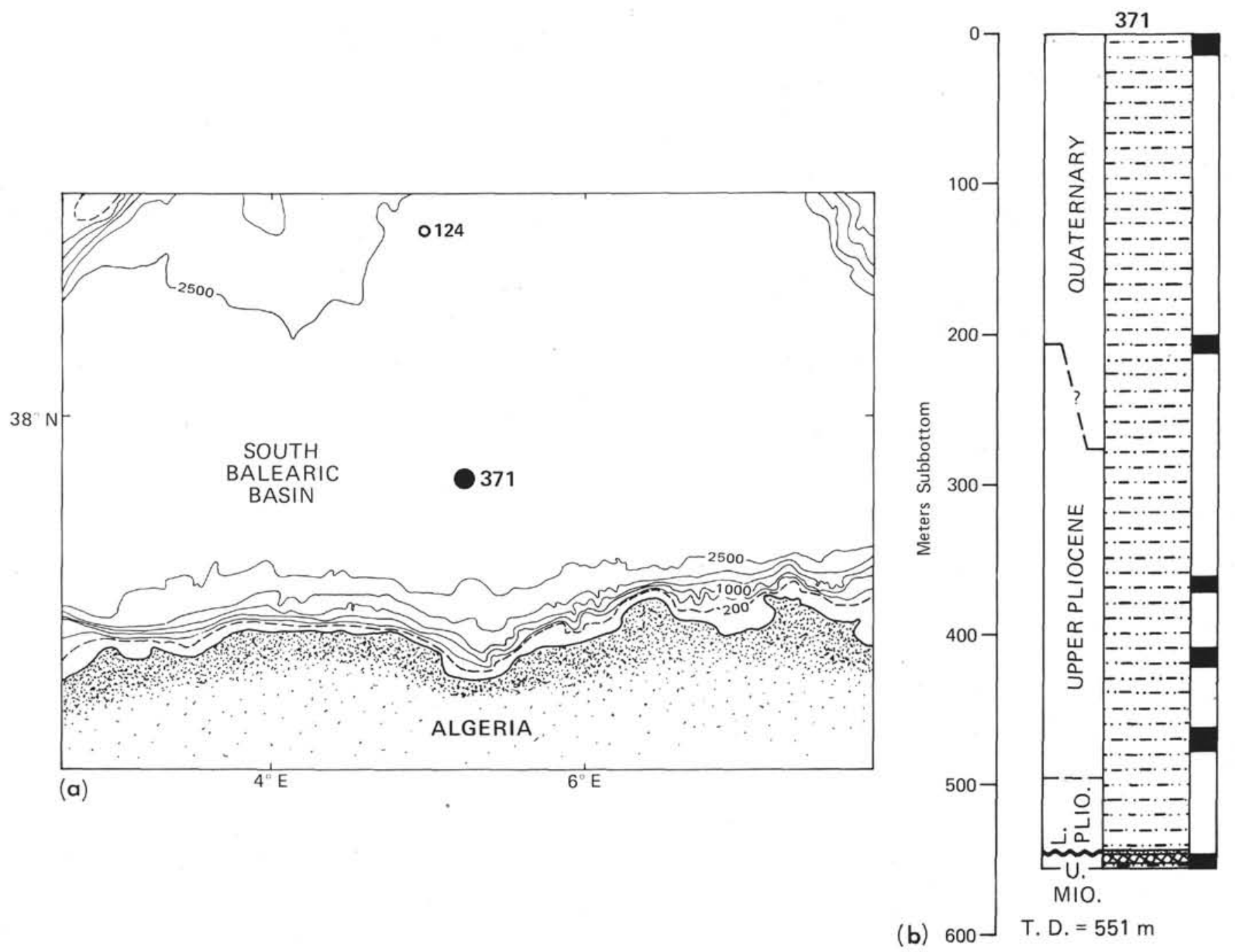

Figure 1. (a) Site location map (depth contours in meters); and (b) generalized hole summary.

The basement is generally believed to be oceanic in the Algero-Provencal Basin following the results of seismic refraction profiles by Fahlquist and Hersey (1969) and more recently by the Institut de Physique du Globe of Paris. The top of layer 3 in this basin could be at about $10 \mathrm{~km}$ below sea level. Very little information is available on the South Balearic Basin. Aeromagnetic surveys (Figure 3) (Bayer et al., 1973) showed the existence of a quiet magnetic zone corresponding to the Balearic Islands area and to the Menorcan Marginal Plateau. In other areas numerous magnetic anomalies are present. It has been proposed that these anomalies suggest a kinematic model of basis genesis by sea-floor spreading (Auzende et al., 1973), although several of the anomalies close to the quiet zone are without doubt volcanoes.

\section{Objectives}

In common with the other small ocean basins, three main hypotheses have been put forward for the genesis of the South Balearic Basin: (1) Subsidence and "oceanization" of a continental crust or of a previously folded area (Pannonian-type basin); (2) Creation of oceanic crust along a spreading ridge; (3) Creation of ocean crust behind a subduction zone (marginal basin).

A final solution of this problem could be provided by drilling the abyssal plain. However, the Mediterranean abyssal plains are almost everywhere underlain by the Messinian evaporitic formation. In the abyssal plain of the South Balearic Basin, numerous basement highs appear on the seismic profiles. They clearly correspond to the magnetic anomalies. Drilling through the evaporites without a blowout prevention device would pose an extreme safety hazard. However, an IFP site survey showed the existence of a basement high corresponding to a magnetic anomaly where the evaporites were either missing or very thin (Figure 4). The prime objective of Site 371 was to determine the nature of the acoustic basement in this target area. If a basalt basement was encountered underlaying the PlioQuaternary pelagic muds, deep crustal penetration here would not present any serious problem, and furthermore a deep crustal site could be proposed here 


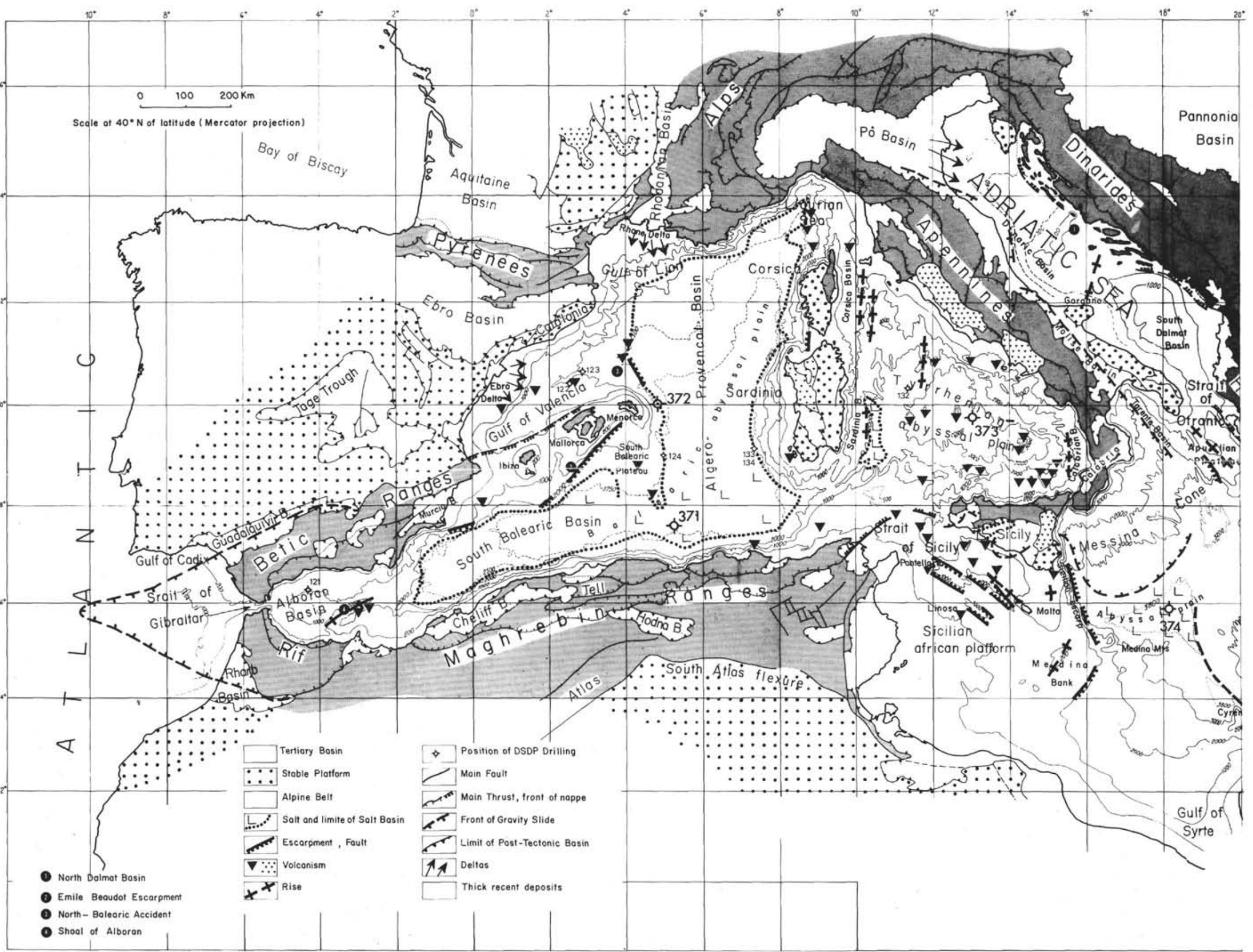




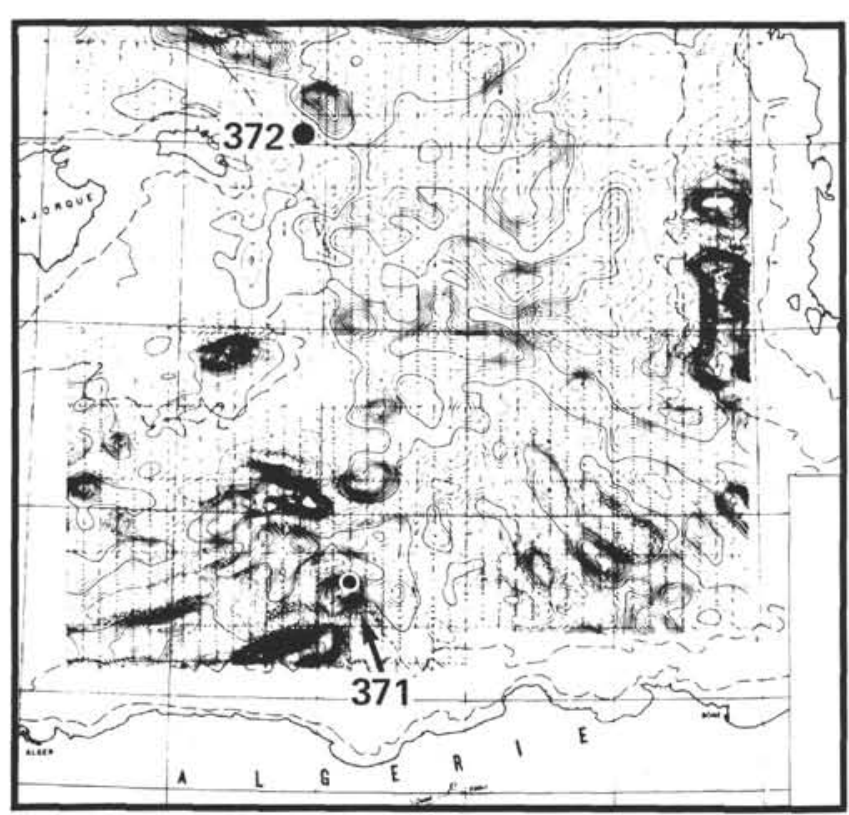

Figure 3. Magnetic anomalies of the Southerr. Balearic Basin (Bayer et al., 1973).

during the IPOD Phase I. If, however, the basement was covered by a thin evaporite veneer, further drilling could be hazardous. If the acoustic basement was basalt, sampling was planned for preliminary petrological and geophysical investigations. On the other hand, if the acoustic basement was made up of evaporite rocks, this would contribute to our understanding of the extent of the Messinian salinity crisis.

\section{OPERATIONS}

\section{Site Approach}

The Glomar Challenger arrived in the target area on the morning of 16 April on a heading of $104^{\circ}$. After intercepting the reference IFP/CNEXO Profile J-103 at about $37^{\circ} 39^{\prime} \mathrm{N}, 05^{\circ} 06^{\prime} \mathrm{E}$, the course was changed at $0602 \mathrm{Z}$ to a $115^{\circ}$ heading to follow the reference profile at a speed of 7.8 knots (Figure 5). Good correlation of seismic profiles was obtained. Speed was reduced to 6.5 knots at $0845 \mathrm{Z}$ about one mile from the target (Figure 6). At $0854 \mathrm{Z}$ the vessel passed over the site and the beacon was dropped on the run. The hydrophone array was retrieved at $0915 \mathrm{Z}$ at which time the vessel turned and homed in on the beacon.

\section{Drilling Program}

After testing the thrusters, the vessel was positioned on semi-automatic at $1400 \mathrm{hr}$ local time (1200Z). The drill string was then assembled. The water depth registered by the position depth recorder (PDR) read

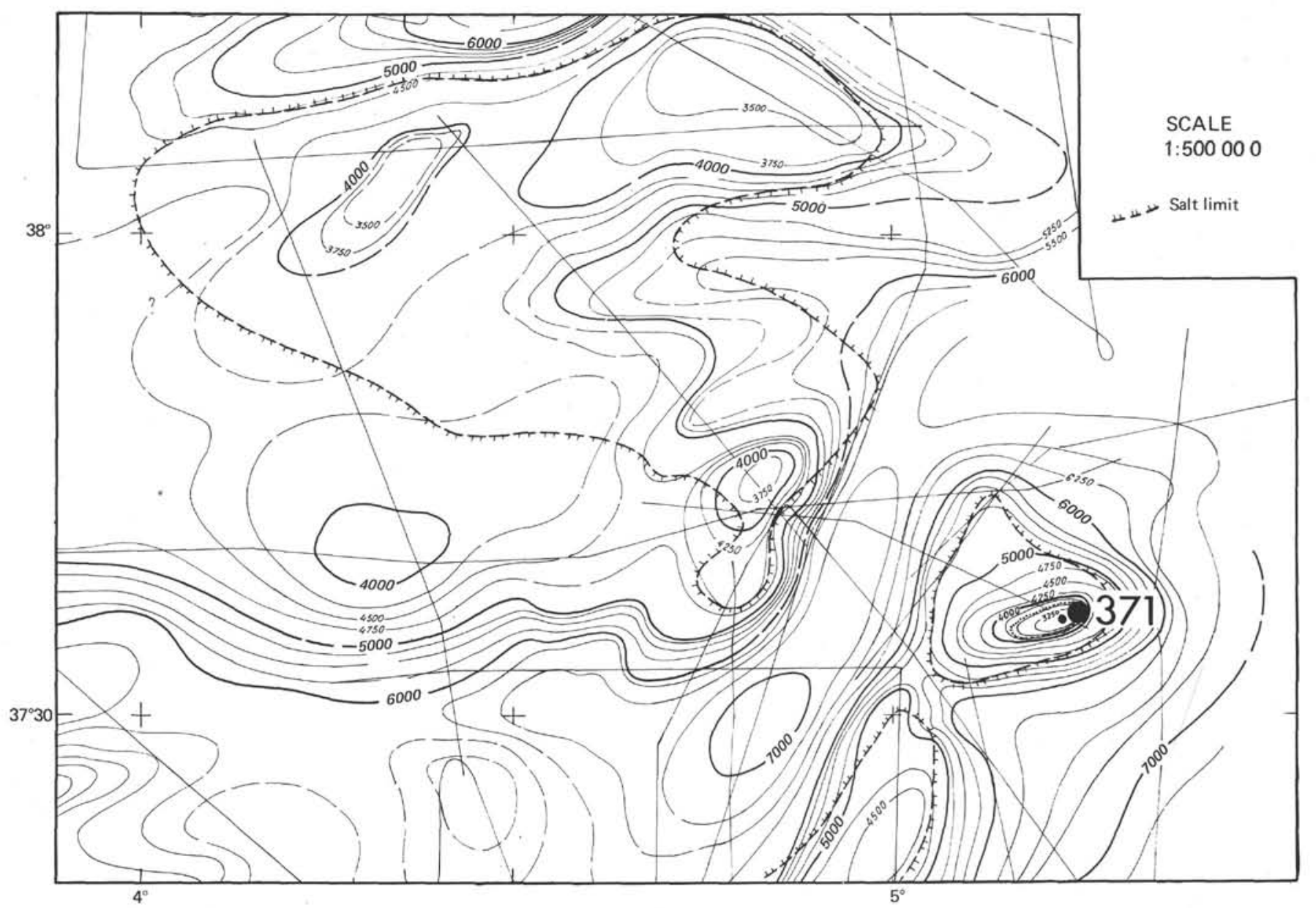

Figure 4. Isobaths of the acoustic basement in the region of Site 371 (IFP/CNEXO survey). 


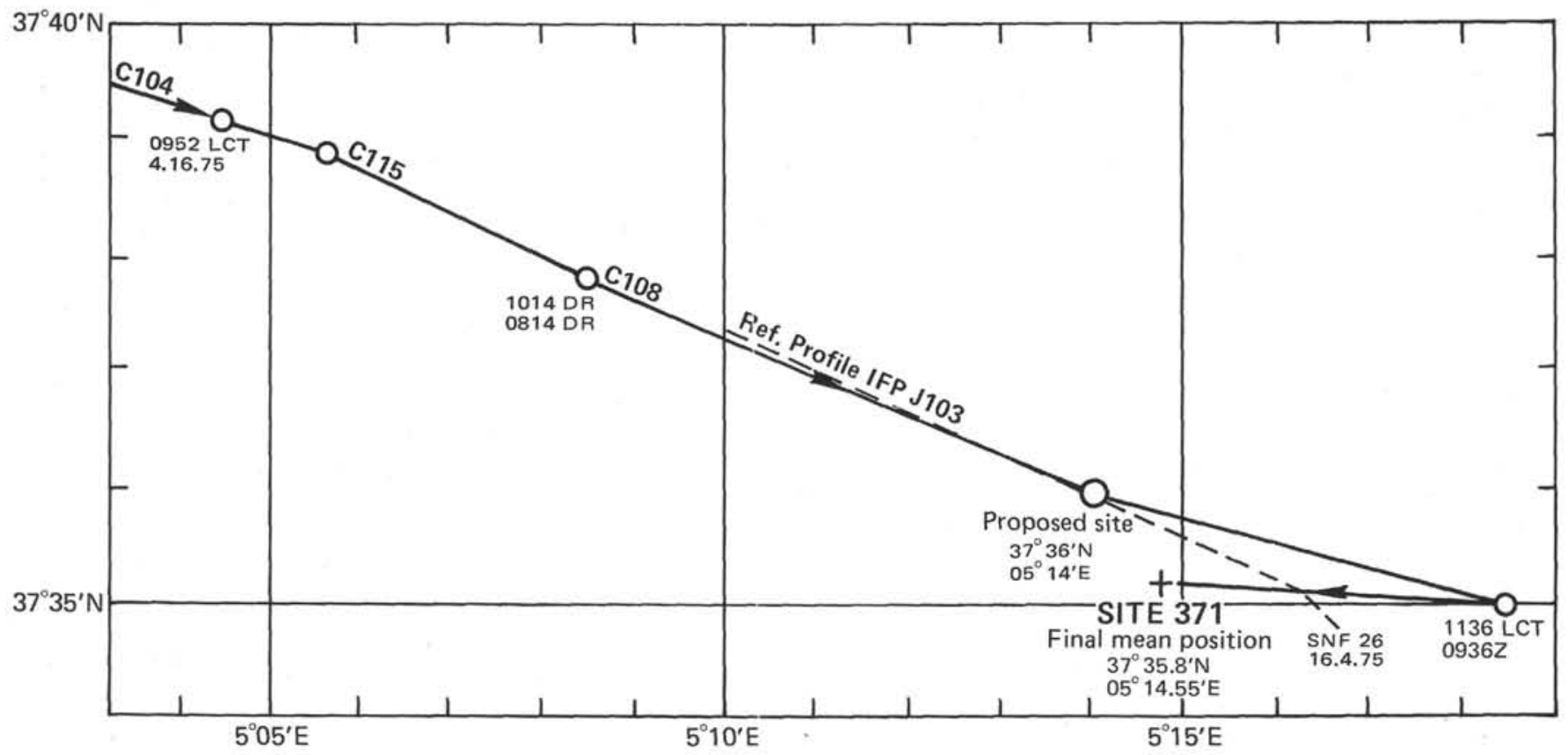

Figure 5. Site approach, Site 371.
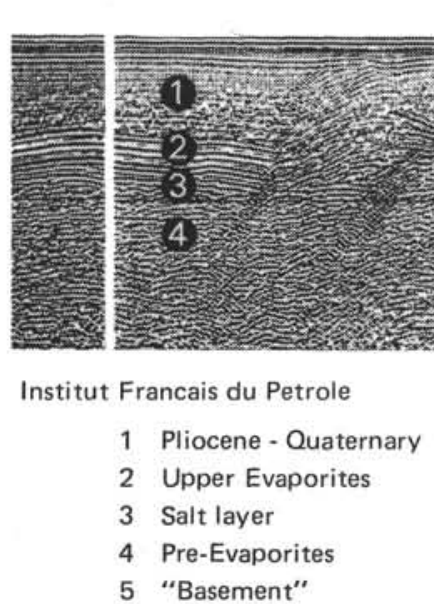

SITE 371

Institut Francais du Petrole

Water depth $2750 \mathrm{~m}$
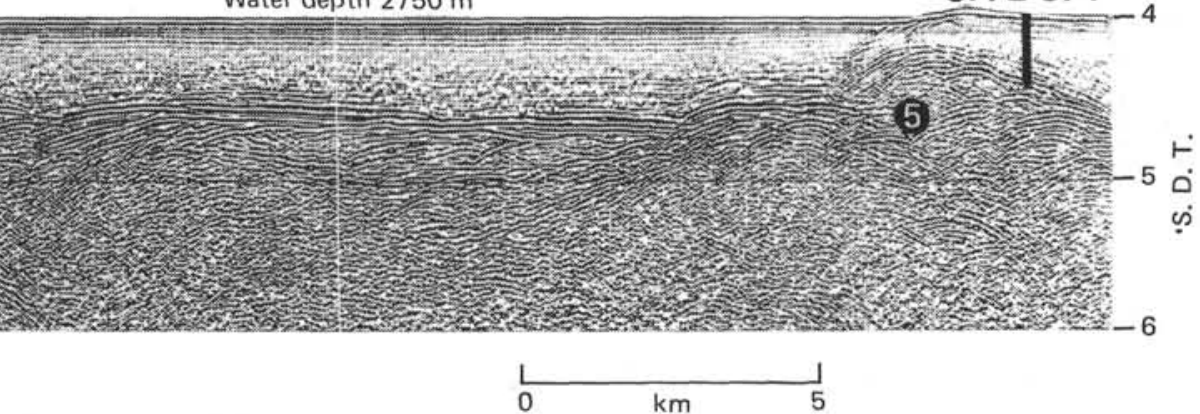

Profile I.F.P.-C.N.E.X.O. J 103

Figure 6. Position of Site 371 on the IFP/CNEXO Profile J103.

2792 meters (corrected). After some delay, because of the need to dispose of defective pipe, the drill string reached the mud line at $2145 \mathrm{hr}$ with a water depth of 2826 meters (or $2816 \mathrm{~m}$ subsea).

A surface core (Core 1) was taken to check the lithology of the sediments immediately subbottom. Six additional cores of Pliocene to Quaternary age were taken between $2240 \mathrm{hr} 16$ April and $2400 \mathrm{hr} 17$ April (see Table 1). Analysis of these cores showed no abnormal hydrocarbon content, but a steady increase of salinity was observed (up to $28 \%$ in Core 7 ). The drilling rate was reduced to less than $5 \mathrm{~m} / \mathrm{hr}$ after Core 7 was cut. A sonobuoy operation to determine the reflector depth beneath the location failed. At 539 meters subbottom, the drilling rate was reported to increase, first slightly and then markedly (see Figure 7). The drilling characteristics indicate penetration of a sandy section. The top of the reflector was reached at about 545 meters subbottom when Core 8, later found to contain anhydrite, was taken. Since the acoustic basement had been reached, and the penetration of evaporites on a basement structure might have presented safety hazards, the decision was made to terminate the hole at $0215 \mathrm{hr}, 18$ April. The drill string cleared the mud line at $0325 \mathrm{hr}$, and the vessel departed for Site 372 at $0900 \mathrm{hr}, 18$ April.

\section{Comments}

There was some difficulty in comparing the site survey and the Challenger's profiles because of the grossly overexaggerated vertical scale of the latter. This led to a survey error. In addition, the beacon may have been displaced during its fall to the sea floor by strong currents. The drill location was eventually found to be 
TABLE 1

Coring Summary, Site 371

\begin{tabular}{cccccccr}
\hline Core & $\begin{array}{c}\text { Date } \\
(\text { April 1975) }\end{array}$ & Time & $\begin{array}{c}\text { Depth From } \\
\text { Drill Floor }\end{array}$ & $\begin{array}{c}\text { Depth Below } \\
\text { Sea Floor } \\
(\mathrm{m})\end{array}$ & $\begin{array}{c}\text { Cored } \\
(\mathrm{m})\end{array}$ & $\begin{array}{c}\text { Recovered } \\
(\mathrm{m})\end{array}$ & $\begin{array}{c}\text { Recovery } \\
(\%)\end{array}$ \\
\hline 1 & 16 & 2240 & $2826.0-2835.5$ & $0.0-9.5$ & 9.5 & 8.3 & 87 \\
2 & 17 & 0230 & $3025.5-3035.0$ & $199.5-209.0$ & 9.5 & 3.8 & 40 \\
3 & 17 & 0700 & $3187.0-3196.5$ & $361.0-370.5$ & 9.5 & 9.0 & 94 \\
4 & 17 & 0930 & $3234.5-3244.0$ & $408.5-418.0$ & 9.5 & 7.9 & 83 \\
5 & 17 & 1330 & $3291.5-3301.0$ & $465.5-475.0$ & 9.5 & 9.5 & 100 \\
6 & 17 & 1905 & $3339.0-3344.0$ & $513.0-518.0$ & 5.0 & 0.2 & 4 \\
7 & 17 & 2150 & $3348.5-3353.0$ & $522.5-527.0$ & 4.5 & 0.2 & 4 \\
8 & 18 & 0215 & $3372.0-3377.0$ & $546.0-551.0$ & 5.0 & 4.4 & 90 \\
\hline
\end{tabular}

1.3 miles east and down the basement slope from the originally proposed site.

There were no technical breakdowns, but there was considerable difficulty in drilling through the more lithified section below 450 meters subbottom. The problem of slow drilling through this compacted mudstone ("waxy shale") could have been solved by the use of a bit with longer cutting teeth. Plugging of the core catcher by compacted mudstone may have prevented entry of sediment into the core barrel, and thus led to the very poor recovery of cores 6 and 7 .

Some special remarks are warranted on the nature of the Plio-Miocene contact. The drilling rate was very slow on the evening of 17 April and core recovery poor. The only samples recovered in Cores 6 and 7 were stiff mudstones lodged in the core catcher. Apparently for each, as soon as a $20-\mathrm{cm}$ cylinder of mudstone had plugged the core catcher, further sediment recovery became impossible. Penetration was accomplished only by washing away the mudstone. After Core 7 was cut, the drilling rate between -527 and -539 meters was very slow (Figure 7 ). We can infer that the Pliocene mudstone was still being drilled. At $0005 \mathrm{hr}, 18$ April, the drilling rate dramatically increased. All the indications were that a sandy section was being penetrated beginning at 539 meters subbottom. This was so unexpected that the interval was washed away before the co-chiefs could give the order to core. This was given with the bit at -546 meters and after the drill string hit the M-reflector at -545 meters. When this core was recovered, $10 \mathrm{~cm}$ of stiff mudstone were found at its top. This overlies anhydrite, which must have been the reflecting horizon. Between the two was a thin lamina of sand a few millimeters thick. We are quite certain that the stiff Pliocene mudstone was lodged in the core catcher while we were trying to wash away the mudstone after Core 7 was cut. It probably came from 528 meters subbottom. We have, therefore, 18 meters of missing section between the Pliocene mudstone in Core 8, Section 1 and the underlying evaporite. The reconstructed stratigraphy is inferred to be:

$\begin{array}{ll}-527 \text { meters } & \text { Base of Core } 7 \\ -528 \text { meters } & \text { Pliocene mud at top of Core 8, Section 1 }\end{array}$

\begin{tabular}{ll}
-529 to -539 meters & $\begin{array}{l}10-\text { meter Pliocene mud interval washed } \\
\text { away }\end{array}$ \\
-539 to -545 meters & $\begin{array}{l}6 \text { meters of sand washed away, but repre- } \\
\text { sented by the fine sand lamina between } \\
\text { Pliocene mud and anhydrite in Core } 8,\end{array}$ \\
& $\begin{array}{l}\text { Section } 1 . \\
-545 \text { to }-546 \text { meters }\end{array}$ \\
1 meter of evaporite washed away. \\
-546 to -551 meters & $\begin{array}{l}\text { Evaporite and silt (as found in Core } 8 \text { be- } \\
\text { low the Pliocene "contaminate"). }\end{array}$ \\
\hline
\end{tabular}

\section{LITHOLOGY}

Site 371 penetrated 551 meters into sediments, on the flanks of a positive subbottom feature within the Southern Balearic Basin and sampled upper parts of a strong reflector met at about 545 meters subbottom. The section was not cored continuously, but since there was little variation in lithologic facies above the reflector, it is felt that a representative sedimentary section was obtained. The site terminated in an evaporite sequence, which, due to safety constraints, was penetrated for only 5 meters.

The section has been divided into two major units based on a major change in facies above and below the reflector (Table 2). Hemipelagic muds and mudstones are underlain by an evaporite sequence.

\section{Unit I}

This unit may be divided into two subunits based on a marked change in drilling characterists below 539 meters subbottom.

The upper subunit (Ia) comprises most of the sedimentary column and is made up of calcareous muds, to mudstones which may be more or less silty, together with calcareous clays and rare marly muds and nannofossil oozes. Intercalated in this sequence of fine-grained sediments are sandy and silty layers. The muds begin to become indurated to mudstones downhole from about 410 meters subbottom. Nowhere do the sandy layers become cemented, although any minor cementation may have been destroyed by the drilling.

Colors generally range from light olive-gray to olive-gray, but minor intervals of moderate yellowishbrown occur in Core 1, which may represent periods of more oxidizing bottom conditions. 


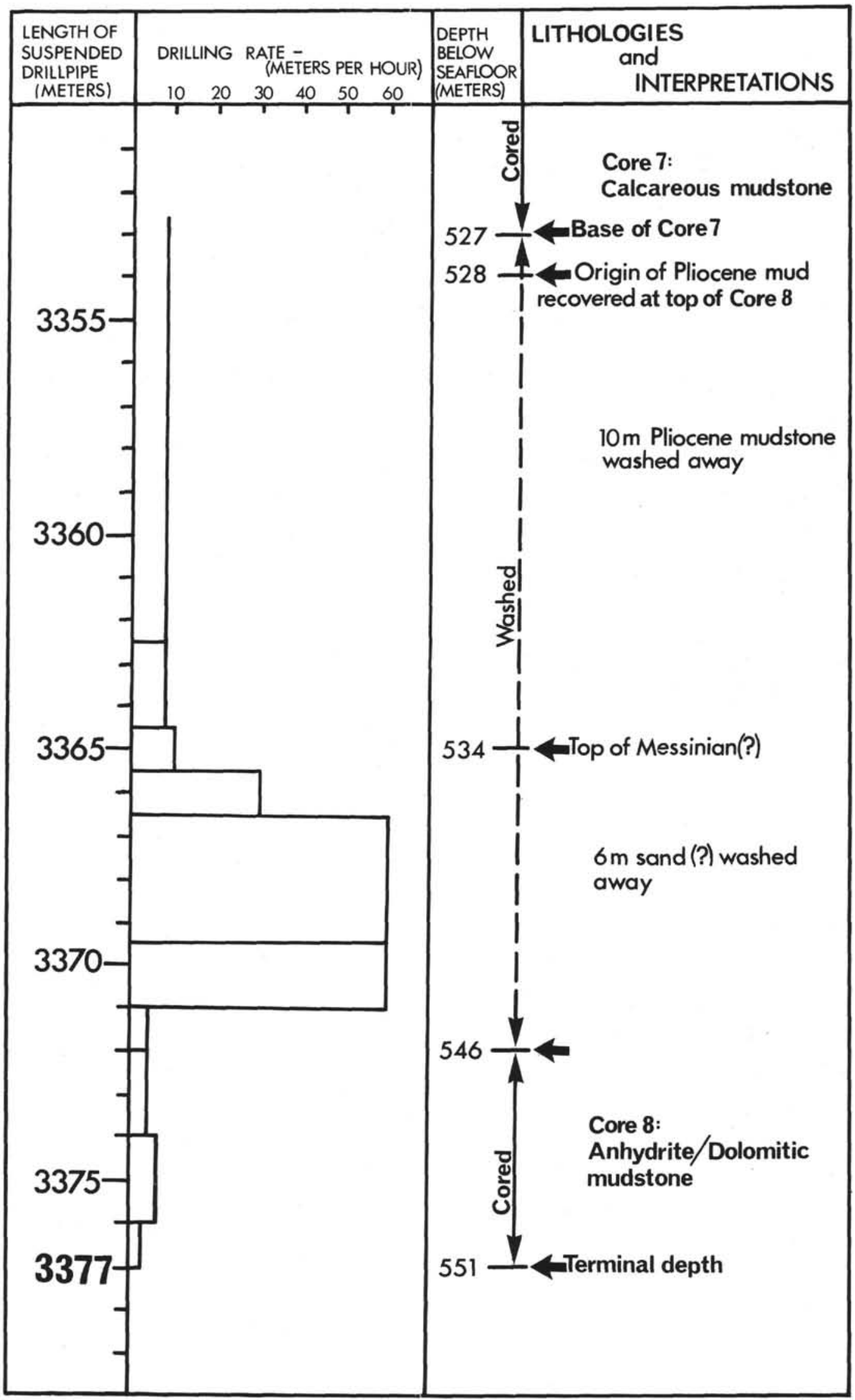

Figure 7. Drilling rates and interpreted lithologies at Site 371. 
TABLE 2

Lithologies at Site 371

\begin{tabular}{|c|c|c|c|c|c|c|}
\hline Unit & & Lithology & Cores & $\begin{array}{l}\text { Subbottom } \\
\text { Depth }(m)\end{array}$ & Thickness (m) & Age \\
\hline \multirow[t]{2}{*}{ I } & a) & $\begin{array}{l}\text { Calcareous muds to } \\
\text { mudstones, with non- } \\
\text { graded and graded } \\
\text { sandy beds and lam- } \\
\text { inae }\end{array}$ & 1.7 & $0-539$ & 539 & $\begin{array}{c}\text { Quaternary } \\
\text { and } \\
\text { Pliocene }\end{array}$ \\
\hline & b) & Calcareous sand & $\begin{array}{c}\text { Extreme } \\
\text { top } \\
\text { Core } \\
8\end{array}$ & $539-545$ & 6 & \\
\hline \multirow{3}{*}{ II } & Ev: & aporites & & & & \\
\hline & a) & $\begin{array}{l}\text { Anhydrite with } \\
\text { dolomitic mudstone } \\
\text { layers }\end{array}$ & $\begin{array}{l}\text { Top } \\
\text { half, } \\
\text { Core } \\
8\end{array}$ & $546-548.5$ & 2.5 & $\begin{array}{c}\text { Upper } \\
\text { Miocene } \\
\text { (Messinian) }\end{array}$ \\
\hline & b) & $\begin{array}{l}\text { Sandy and silty } \\
\text { dolomitic mudstone }\end{array}$ & $\begin{array}{c}\text { Basal } \\
\text { half, } \\
\text { Core } \\
8\end{array}$ & $548.5-551$ & 2.5 & \\
\hline
\end{tabular}

Mottling is present throughout the finer sediments. Chondrites-type burrows and larger forms of Zoophycos-type are recognizable in the less-disturbed cores downhole from 360 meters subbottom.

Both nongraded and graded sandy layers are present in this unit. Numbers of intercalated beds and laminae increase markedly downhole from 23 in Core 1 to 64 in Core 5. Of these, between $50 \%$ and $75 \%$ are graded in Cores 1 and 2, between $9 \%$ and $6 \%$ only in Cores 3 and 4, and 20\% in Core 5. Almost all have sharp basal contacts many of which are clearly erosional with channel-and-fill features. Mottling and burrows in the muds or mudstones end abruptly against the basal contacts of these sandy interbeds. Such erosional contacts are well displayed in Cores 3 and 5. Muds in Section 5-5 have a "flaser bedding" appearance which may here indicate slumping.

Average sand content in the calcareous muds varies little and is everywhere below $10 \%$. On the other hand, the amount of sand in the calcareous interbeds increases downhole to a maximum of $40 \%$ in Core 5 . Carbonate values also increase slightly downhole from around $30 \%$ in Core 1 to around $40 \%$ in Core 5.

Smear-slide analysis shows that the calcareous muds and mudstones are principally composed of clay, detrital carbonate, nannofossils, and quartz with rare dolomite, feldspar, and foraminifers. Resedimentation of much of the material is indicated by the appearance of discoasters in Pleistocene cores and by the abraded nature of rhombs of carbonate. In addition many of the foraminifers are micritized or have pyrite in their chambers.

$\mathrm{X}$-ray analyses of the muds and mudstones show that illite and mixed-layer clay minerals comprise over a third of their bulk mineralogy throughout the sequence, with minor amounts of chlorite and kaolinite. The feldspar component proves to be mostly plagioclase. A general trend of decreased clay and quartz/ feldspar content downhole opposes that for carbonate as recorded above.

The intercalated sandy layers have similar major components to the fine-grained sediments. Quartz, clay minerals, and detrital carbonate are common to abun- dant throughout. Nannofossils are common and foraminifers may be either common or rare. Amorphous iron oxides, fish and plant debris, pyrite, and dolomite appear as traces or are rare. Most of the quartz is angular, but some rounded grains with iron oxide coatings were recognized in Cores 3 and 4 . Volcanic glass appears in traces in the sandy beds within Core 2 and gypsum clasts are present in those of Cores 5, 6, and 7 .

Subunit $\mathrm{Ib}$ is a 6-meter-thick calcareous sand bed whose existence has been inferred from drilling characteristics as described in the operations report. Its only representative in the recovered materials is a thin sand lamina which overlies the evaporites of Unit II. It is made up primarily of fragments of detrital carbonate and gypsum together with nannofossils, forams, and dolomite.

On the basis of these observed lithologies, the environment of deposition appears to have undergone little change. The topmost core, Core 1, which represents present-day sedimentation at a water depth of 2792 meters, is not markedly different from Core 5, the lowest full core in the unit. Hemipelagic sedimentation at this site has been very intermittent with periods of relatively slow deposition, allowing extensive bioturbation of the fine sediments. These alternated with erosional phases and periods of relatively rapid deposition of sand and silt. The bioturbation is indicative of unrestricted basin circulation. The sandy layers may in part have been emplaced by distal turbidity current activity as is suggested by their grading, lamination, and composition. Reworking of such material once emplaced, producing other laminated beds, but with no grading, is also likely to have taken place. Deposition appears to have been on a knoll slightly above the surrounding sea floor and consequently the location would have been more exposed to contour-current type activity. The apparent downhole increase in both number of beds and laminae and detrital content may be indicative of elevation changes on the basin margins or even the progressive burial of a local sand source. Much of the detrital carbonate of the fine-grained sediments was probably transported to the basin by prevailing winds from the desert areas to the south.

\section{Unit II}

This unit, cored only in Core 8 , differs markedly from Unit $I$ in that it is made up of sediments with evaporitic minerals as a major component. It has been divided into two subunits: an upper 2.5 meters of anhydrite (Subunit IIa) overlaying 2.5 meters of dolomitic mudstone (IIb).

Subunit IIa is made up of a hard white anhydrite, in places broken and disturbed by the drilling, but in others displaying specific structural features. Near its upper contact thin layers of detrital material interbedded in the anhydrite display a wavy lamination known as stromatolitic structure which is inferred to be of algal origin (Figure 8). At around $80 \mathrm{~cm}$ in section $8-2$ the anhydrite is nodular form referred to as "chickenwire" structure (Figure 9). Thin interbeds of dolomitic mudstone appear at intervals within the anhydrite 


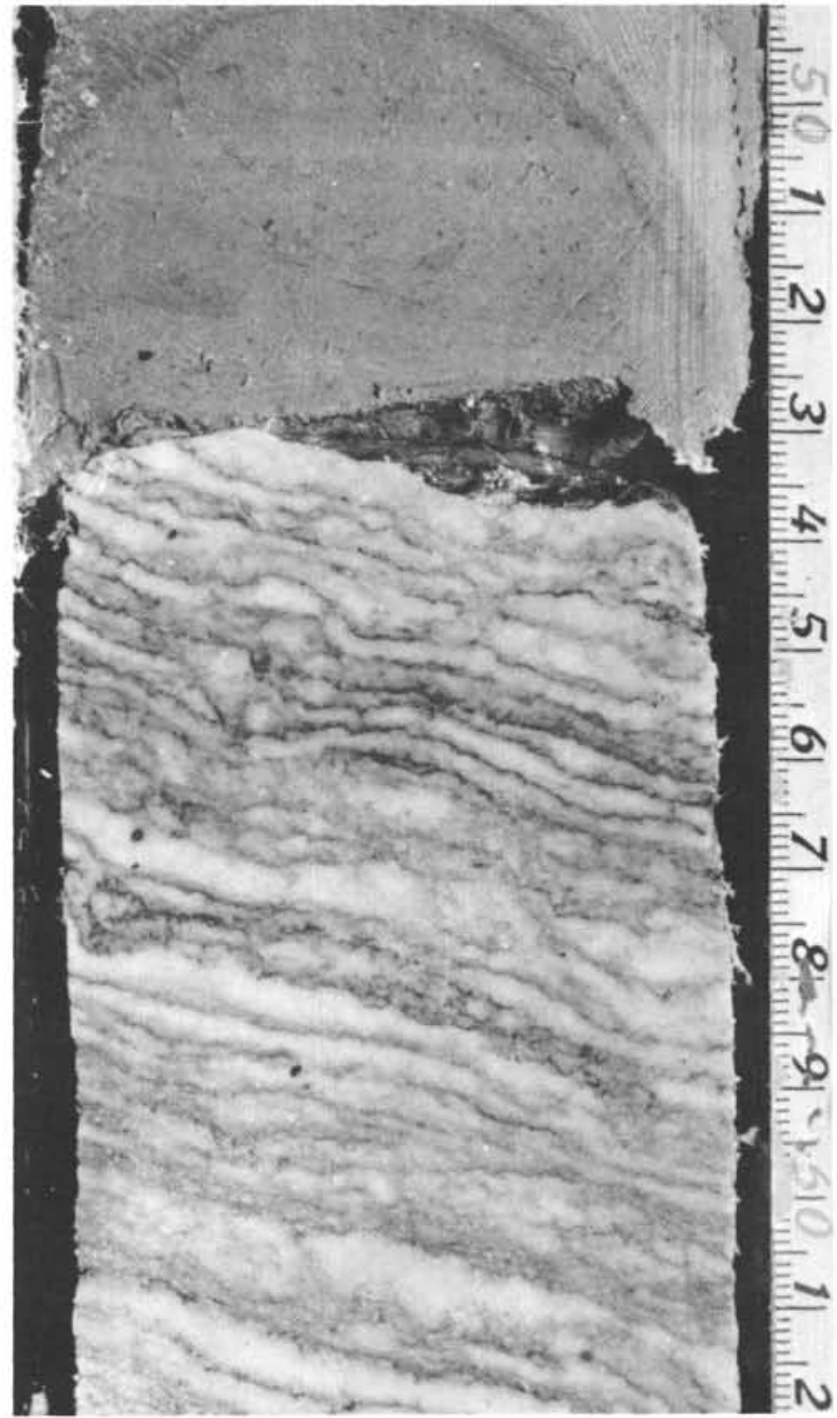

Figure 8. Anhydrite at the top of Site 371, Core 8 displaying stromatolitic structure. The anhydrite is overlain by lower Pliocene calcareous mudstone with sand. This contact is a drilling artifact.

sequence. Clay is the dominant sedimentary component of these layers and dolomite is common. Rare detrital carbonate, anhydrite, and gypsum clasts are also present.

Below Sample 8-2, $95 \mathrm{~cm}$ the lithology becomes entirely dolomitic mudstone through to the base of the hole. This mudstone is, however, coarser than those described further up the sequence, containing $26 \%$ sand and less than $34 \%$ clay. The clay mineralogy is not illite/mixed-layer dominated; here chlorite and kaolinite are of equal importance. Dolomite comprises half the total carbonate present. A frosted surface texture was observed on some of the quartz grains which is indicative of a desert source. Micro-meteorite particles appear in trace amounts.

The sediments of Subunits IIa and IIb, on the basis of their composition and diagnostic structures and by analogy with recent environments, are interpreted as subaerial (sabkha) and lagoonal deposits, respectively,

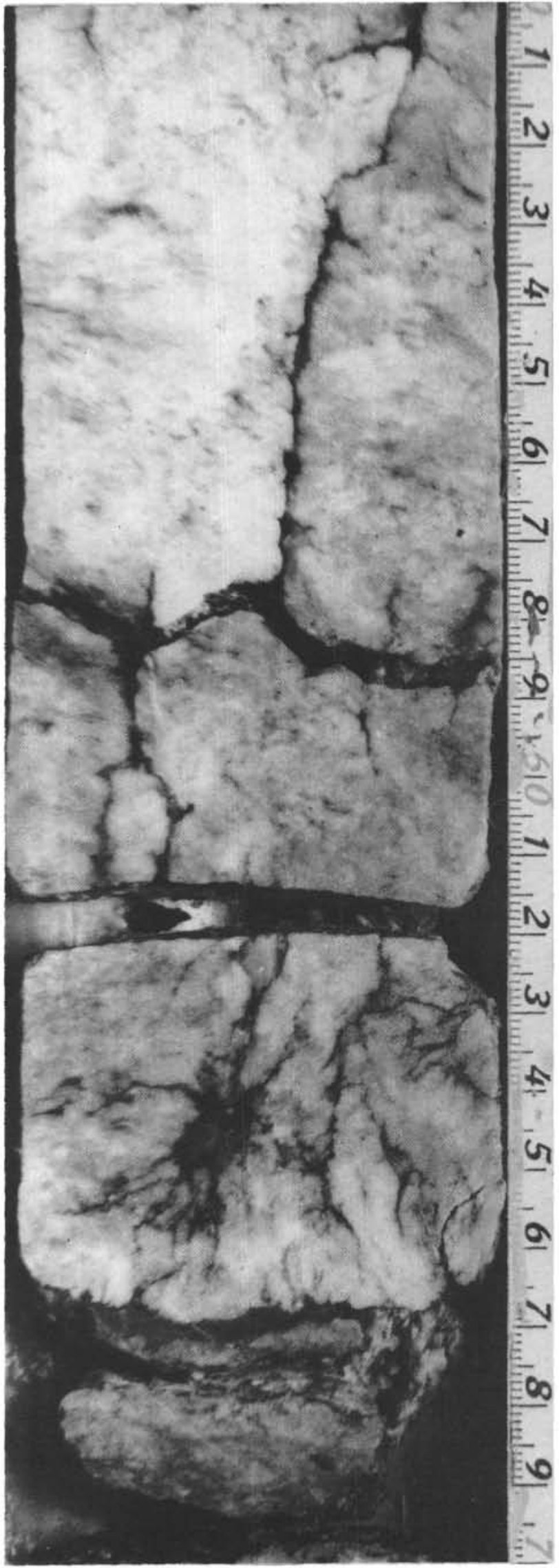

Figure 9. Nodular anhydrite at Site 371, Core 8 displaying "chicken wire" structure. 
(Garrison et al., this volume). These inferred environments of deposition are in striking contrast to the hemipelagic environment suggested by the mudstones and muds of Unit I. The contact between the two was unfortunately almost entirely lost during drilling, and its nature can only be surmised. It should be noted, however, that clasts, presumably derived from the evaporite sequence, appear important in the sand, which overlies the anhydrite. This would suggest that a terrain of evaporitic rocks was exposed in places during the deposition of the earliest Pliocene sediments.

\section{GEOCHEMICAL MEASUREMENTS}

\section{Interstitial Water}

After squeezing the interstitial water, $p \mathrm{H}$, alkalinity, chlorinity, salinity, and $\mathrm{Ca}^{++}$and $\mathrm{Mg}^{++}$contents were measured for sediments recovered at Site 371 (see Figures 10 and 11 and Table 3 ). The $p \mathrm{H}$ values vary from a high of 8.16 (Core 3 ) to a low of about 5.27 (Core 7). The alkalinity drops to values below 1 (Cores 2-5), but increases to 2.91 in the last core. Chlorinity and salinity show an increasing trend to extremely high values in the lowermost core where the interstitial water is oversaturated with respect to $\mathrm{NaCl}$. Together with the increasing salinity, the concentrations of $\mathrm{Ca}^{++}$and $\mathrm{Mg}^{++}$cations also increase to very high values. The $\mathrm{Ca} / \mathrm{Mg}$ ratio in the surface water of Site 371 and in the uppermost core is near 0.2 , but the ratio is more or less 1 in Core 2 and deeper. The values suggest an equilibrium of the interstitial waters with calcite and dolomite.

\section{Carbonate Content}

The carbonate content of Cores 1 to 5 and Core 8 were measured onboard ship by the "carbonate bomb." In most sections two samples were analyzed, one from the dominant lithology and another from the minor lithology. These, together with the shore-base analyses (LECO-DSDP) are plotted against the hole summary. The $\mathrm{CaCO}_{3}$ content varies considerably, but commonly is within a range of $25 \%$ to $50 \%$, with a maximum of $54 \%$ in Cores 4-6. Low values from Core 1 and Core 8 are related to high detrital content. No corrections for the dolomite content were made.

\section{PHYSICAL PROPERTIES}

\section{Sonic Velocity Data}

Sound velocity increased slowly from about 1.53 $\mathrm{km} / \mathrm{sec}$ at a depth of 5 meters subbottom to values of about $1.72 \mathrm{~km} / \mathrm{sec}$ at 369 meters subbottom (Table 1 of Appendix VI). Sediments between 415 and 513 meters subbottom, recovered in Cores 4,5 , and 6 , showed a more rapid, but fairly constant rate of increase in velocity with depth from 1.88 to $3.08 \mathrm{~km} /$ sec. Within this interval the calcareous muds slowly become indurated enough to be considered mudstones, and traces of gypsum, which first appear in Core 5, increase in abundance downhole. Both the number and coarseness of graded and nongraded sandbeds also increase from the top of the hole down to the base of the mud-mudstone limit at a depth of 545 meters subbottom.

Compressional velocities averaging about $5 \mathrm{~km} / \mathrm{sec}$ were measured through a well-consolidated chunk of anhydrite containing "chicken-wire" structure which was recovered from 547.4 meters subbottom. The consolidation of both the anhydrite, and sediments recovered from higher up in the hole, permitted sound velocity to be measured on chunks of sediment in both the horizontal and vertical directions. The results of these measurements show that sound travels more rapidly in the horizontal direction, parallel to bedding planes, than in the vertical direction (Table 2 of Appendix VI).
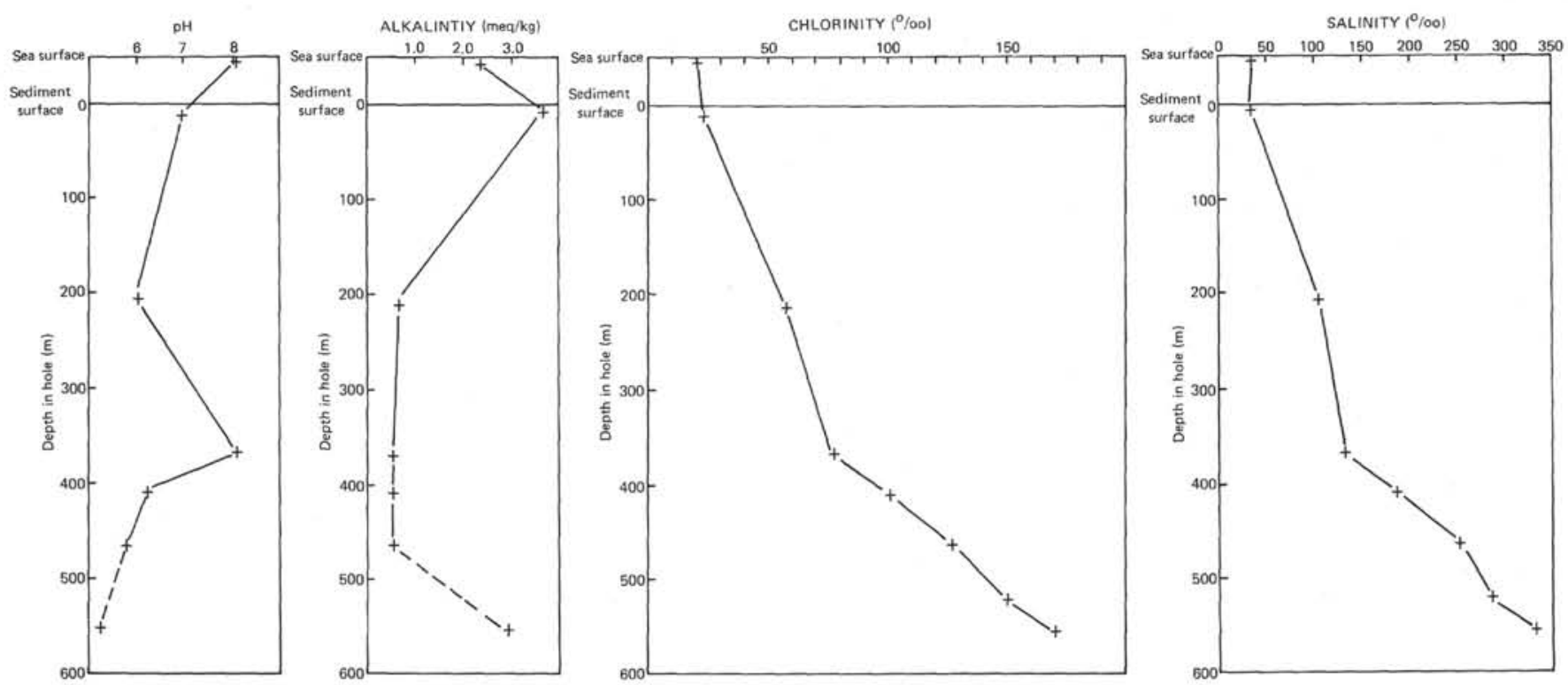

Figure 10. Geochemical measurements at Site 371: $\mathrm{pH}$, alkalinity, chlorinity, and salinity. 
$\mathrm{Ca}^{++} \& \mathrm{Mg}^{++}$(mmoles $/$)

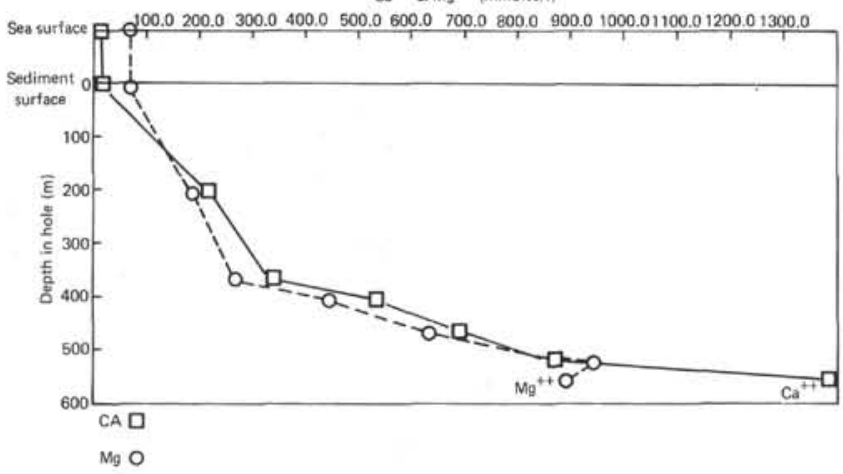

Figure 11. Geochemical measurements at Site 371: $\mathrm{Ca}^{++}$ and $\mathrm{Mg}^{++}$.

\section{Wet Bulk Density, Porosity, and Water Content}

These properties were measured using both gravimetric and gamma ray attenuation methods (Tables 3, 4 , and 5 of Appendix VI). Density determined in the calcareous muds and mudstones in lithologic Unit 1 using the gamma ray attenuation method are almost always higher than density values measured using the syringe sampling technique, and lower than values measured on minicylinders. The average core density, as determined by the gamma ray attenuation method, increases from $1.69 \mathrm{~g} / \mathrm{cc}$ near the mudline to $2.03 \mathrm{~g} / \mathrm{cc}$ at about 474 meters subbottom near the base of Unit I, and then increases abruptly to $2.28 \mathrm{~g} / \mathrm{cc}$ in the anhydrite and dolomitic mudstone recovered in Core 8.

\section{Shear Strength}

A single shear strength measurement was made at one location in each of the first four cores immediately after the cores were split (Table 6 of Appendix VI).
Because the sediments are silty clays, rather than pure clays, the significance of the vane shear strength data is questionable. Shear strength values range from 0.045 $\mathrm{kg} / \mathrm{cm}^{2}$ at 5.6 meters subbottom to $1.401 \mathrm{~kg} / \mathrm{cm}^{2}$ at 415.6 meters subbottom.

\section{Thermal Conductivity}

Eleven thermal conductivity values were obtained in the calcareous muds and mudstones between 5.8 and 473.5 meters subbottom (Table 7 of Appendix VI). The average thermal conductivity was $3.53 \pm 0.33$ $\mathrm{mcal} / \mathrm{cm} \mathrm{sec}{ }^{\circ} \mathrm{C}$. Values ranged from 3.12 to $4.33 \mathrm{mcal} /$ $\mathrm{cm} \mathrm{sec}{ }^{\circ} \mathrm{C}$, with a weak tendency for the higher values to occur deeper in the hole. The presence of numerous, thin, sandy and sandy-silt layers within the cored material may be responsible for some of the observed variability, and for the lack of the expected gradual increase in conductivity with depth as pore water is expelled during compaction.

\section{BIOSTRATIGRAPHY}

\section{Summary}

The sedimentary succession penetrated at Site 371 ranged in age from Quaternary to late Miocene and was terminated in Messinian evaporites at 551 meters subbottom. Coring was discontinuous and core recovery was such that less than $10 \%$ of the total thickness penetrated could actually be examined; therefore a detailed biostratigraphic study could not be undertaken. Most zonal boundaries fall within uncored intervals and consequently cannot be precisely located (see Figure 12).

The essentially hemipelagic sediments of Pleistocene and Pliocene age were moderately to richly fossiliferous in well-preserved planktonic foraminifers and

TABLE 3

Summary of Shipboard Geochemical Measurements, Site 371

\begin{tabular}{|c|c|c|c|c|c|c|c|c|}
\hline $\begin{array}{c}\text { Sample } \\
\text { (Interval in } \mathrm{cm} \text { ) }\end{array}$ & $\begin{array}{l}\text { Depth Below } \\
\text { Seafloor } \\
\text { (m) }\end{array}$ & $p \mathrm{H}$ & $\begin{array}{l}\text { Alkalinity } \\
(\mathrm{meq} / \mathrm{l})\end{array}$ & $\begin{array}{l}\text { Salinity } \\
(\% / 00)\end{array}$ & $\begin{array}{c}\mathrm{Ca}^{++} \\
(\mathrm{mmoles} / \mathrm{l})\end{array}$ & $\underset{(\mathrm{mmoles} / \mathrm{l})}{\mathrm{Mg}^{++}}$ & $\begin{array}{c}\text { Chlorinity } \\
(\% / 00)\end{array}$ & $\begin{array}{l}\text { Lithologic } \\
\text { Unit }\end{array}$ \\
\hline $\begin{array}{l}\text { Surface } \\
\text { Seawater } \\
\text { Reference }\end{array}$ & & & & & & & & \\
\hline $\begin{array}{l}\text { (1) } \\
\text { (2) }\end{array}$ & $\begin{array}{l}- \\
-\end{array}$ & $\begin{array}{l}7.78 \\
8.05\end{array}$ & $\begin{array}{l}2.30 \\
2.37\end{array}$ & $\begin{array}{l}35.2 \\
37.4\end{array}$ & $\begin{array}{l}10.55 \\
11.233\end{array}$ & $\begin{array}{l}53.99 \\
58.227\end{array}$ & $\begin{array}{l}19.375 \\
20.361\end{array}$ & - \\
\hline $\begin{array}{l}1-5, \\
144-150\end{array}$ & 8.0 & 6.90 & 3.58 & 40.7 & 14.213 & 63.579 & 22.331 & \\
\hline $\begin{array}{l}2-2, \\
144-150\end{array}$ & 207.44 & 5.94 & 0.633 & 103.0 & 219.8 & 188.3 & 57.791 & \\
\hline $\begin{array}{l}3-5, \\
144-150\end{array}$ & 386.44 & 8.16 & 0.567 & 133.6 & 335.1 & 264.6 & 76.186 & I \\
\hline $\begin{array}{l}4-5 \\
146-150\end{array}$ & 406.96 & 6.18 & 0.554 & 185.9 & 536.3 & 440.2 & 100.487 & \\
\hline $\begin{array}{l}5-5, \\
140-150\end{array}$ & 463.9 & 5.76 & 0.569 & 253.0 & 691.6 & 633.9 & 127.152 & \\
\hline $6, \mathrm{CC}$ & 518.0 & - & - & 286.0 & 867.4 & 944.4 & 155.205 & \\
\hline $\begin{array}{l}8-2, \\
140-150\end{array}$ & 549.4 & 5.27 & 2.91 & 332.2 & 1380.0 & 894.8 & 170.434 & \\
\hline
\end{tabular}


SITE 371: SOUTH BALEARIC BASIN

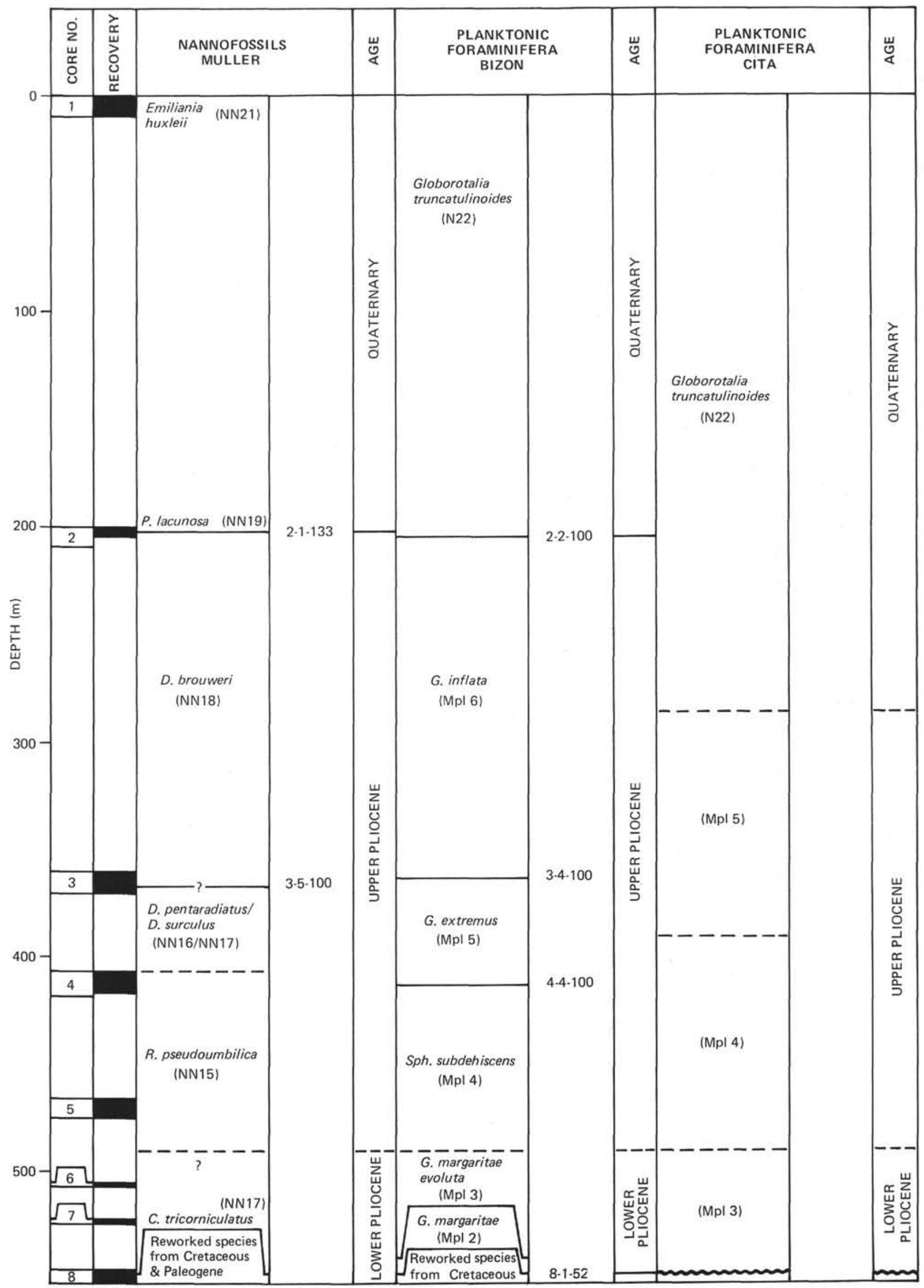

T. D. $=551$ meters

Figure 12. Relative planktonic microfossil determinations, Site 371. 
nannoplankton while benthic foraminifers were less abundant. The ratio of planktonic to benthic foraminiferal tests was consistently high (>90\%) indicating water depths in excess of 1000 meters. Reworking from older formations is common in most of the sediments investigated. This reworking is most evident among the nannofossils (displaced Cretaceous and Neogene forms). Small reworked upper Cretaceous planktonic foraminifers are common om Core 2, Section 2 to Core 8.

Displacement of benthic foraminifers from shallower environments is common in the Pliocene section. The presence of tunicate spicules in the Quaternary sediments further indicates displacement of material from shelf areas.

Quaternary ages were determined in Core 1 to Core 2, Section 2 (0 to $201 \mathrm{~m}$ subbottom) and in Core 3 also, according to Cita. The determination of the Pleistocene-Pliocene boundary is difficult and will be discussed in later sections of this site report.

A late Pliocene age was assigned to the sequence between Core 2, Section 3 and Sample 5, CC (202 to $475 \mathrm{~m}$ subbottom).

Core 6 to Sample 8-1, $52 \mathrm{~cm}$ belongs to the lower Pliocene (513 to $546.5 \mathrm{~m}$ subbottom). Below this interval, only reworked Cretaceous and Paleogene species were found.

Sixteen meters of section are inferred to be missing between the Pliocene mudstone lodged in Core 8 , Section 1, but believed to be from -528 meters, and the underlying evaporites. Consequently, it was impossible to investigate in detail the lowest part of the Pliocene. The evaporitic sequence is barren of indigenous microfossils. Its Messinian age is inferred.

Nannofossils

\section{Quaternary}

Sediments of the Quaternary in general are rich in well-preserved nannoplankton. Reworked species of the Cretaceous, Plaeogene, and Neogene are more frequent in the upper Pleistocene (NN 20/NN 21) than in the lower Pleistocene (NN 19). A relationship was observed between the abundance of nannofossils and the amount of detrital material by which the content of nannoplankton is diluted. It is characteristic of the turbidite sediments of this sequence. Reworked species and tunicate spicules (indicating shallower water) are more frequent in these sediments.

Core 1 belongs to the Emiliania huxleyi Zone (NN 21). The nannoplankton assemblage is typical of the transitional zone (McIntyre et al., 1967). Dominant species are: Helicosphaera carteri, Rhabdosphaera clavigera, Coccolithus pelagicus, Gephyrocapsa oceanica (small), and Syracosphaera pulchra. Umbilicosphaera mirabilis, Umbellosphaera tenuis, and Gephyrocapsa oceanica, which are typical of the subtropical zone, are rare. Sample 1-2, $80-81 \mathrm{~cm}$ is abundant in Braarudosphaera bigelowi. The Pseudoemiliania lacunosa Zone (NN 19) was determined in Core 2, top, to Sample 2, 133-134 cm (198.0-201.0 m subbottom). Reworked species are present only sporadically. Samples 2-2, 14 $15 \mathrm{~cm}$ to $2-2,23-24 \mathrm{~cm}$ and Sample 2-2, 133-134 cm are abundant in a large variety of Braarudosphaera bigelowi. Horizons distinguished by the presence of this variety are also described by Stradner (1973) from the Tyrrhenian Sea (Site 132) in the lowermost Pleistocene. Pseudoemiliania lacunosa is only rare in this horizon.

\section{Pliocene}

The determination of the Plio/Pleistocene boundary in the section at Site 371 is difficult because discoasters are only rare, and they seem to have an earlier extinction. The boundary is determined by the last abundant occurrence of Cyclococcolithus macintyrei between Sample 2=2, 133-134 cm and 2-2, 1-2 cm. This biostratigraphic event is associated with a distinct decrease of Coccolithus pelagicus, a species of cooler waters. The first discoasters were found in Sample 3-5, 100-101 cm which indicate the presence of the Discoaster surculus Zone (NN 16). The occurrence of discoasters is more or less restricted to specific horizons. They are generally only rare in the Pliocene sediments at Site 371.

The Reticulofenestra pseudoumbilica Zone (NN 15) was determined from Samples 4-1, 142-143 cm to 5, CC. This zone is distinguished by an abundance of Discoaster tamalis and Reticulofenestra pseudoumbilica. In the upper part of this zone only a small variety of Reticulofenestra pseudoumbilica is present. Sediments are rich in well-preserved nannofossils. Reworked species of the Cretaceous and Paleogene were observed only sporadically or are missing. Scyphospheres are more or less abundant. Ceratolithus rugosus was found only in Sample 5, CC. Discoasters are present only rarely in Samples 6, CC and 7, CC. An exact age determination for these samples is impossible. In Sample 8-1, 48-49 cm, Ceratolithus tricorniculatus was observed. Autochthonous nannofossils are rare in Section 2 of this core while reworked species of the Cretaceous and Paleogene are more frequent. Nannofossils are missing in the lowermost part of Core 8. It probably belongs to the Ceratolithus tricorniculatus Zone (NN 12); at least the upper part of this core. An exact age determination is difficult because of the scarcity of discoasters and ceratoliths.

\section{Planktonic Foraminifers (Cita)}

Forty-three sediment samples were investigated in all. The reader is referred to Chapter 49 (Bizon et al., this volume) where a detailed range chart is included.

\section{Holocene and Pleistocene}

The Holocene (= postglacial, younger than $9000 \mathrm{yr}$ ) was documented in the topmost part of Core 1, where perfectly preserved foraminiferal tests with tiny spines, pink colored Globigerinoides ruber, and delicate aragonitic tests of pteropods are present in a rich and diversified assemblage indicating warm-temperature climatic conditions.

Evidence of climatic fluctuations is found in the sections below Section 1 of Core 1. Core 2, also 
referred to the Pleistocene, is considered to belong to the so-called "pre-glacial"' Pleistocene (see Cita et al., 1972).

\section{Pliocene/Pleistocene Boundary}

Because of the drilling program employed at Site 371 (spot-coring, washing for over $150 \mathrm{~m}$ between Cores 2 and 3, with the core barrel in place throughout) the precise location of the Pliocene/Pleistocene boundary is questionable. Core 3 has six sections: the foraminiferal faunas yielded by sections 4 to 6 are characteristic of the M Pl-5 biozone, with Globigerinoides obliquus extremus, Globorotalia aemiliana, $G$. bononiensis $G$. puncticulate, etc. Of the three samples investigated from Sections 1 to 3, two (namely, 3-1, 95 $\mathrm{cm} ; 3-3,100 \mathrm{~cm}$ ) yield in abundnace Globorotalia inflata in an advanced evolutionary stage, i.e., large size, with a broadly rounded periphery, tightly coiled, smooth and bright surface, as typically recorded from the Pleistocene. The latter sample also yielded Globorotalia oscitans, a typical Pleistocene Mediterranean species. The third sample $(3-2,63 \mathrm{~cm})$ has practically no fraction greater than $63 \mu \mathrm{m}$, which is strange indeed. Consequently, there is strong evidence that several meters of sediments from the upper half of Core 3 are Pleistocene in age; they were probably introduced into the core barrel during the 150 meters of penetration when no core was cut. Their presence is not sufficient to locate the Pliocene/Pleistocene boundary within Core 3 , or at approximately 365 meters subbottom. Also for calculating the sedimentation rates, this author considers it safer to arbitrarily locate the Pliocene/Pleistocene boundary halfway within the uncored interval between Cores 2 and 3 .

\section{Late Pliocene}

Late Pliocene sediments are contained in Cores 3, 4, and 5 ( 361 to $475 \mathrm{~m}$ subbottom). M Pl-5, the penultimate biozone of the Pliocene, was identified in Core 3, as discussed above. The assemblages are rich and diversified. Noteworthy is the occurrence of Sphaeroidinella ionica ionica, a taxon seldom recorded in the late Pliocene of the Mediterranean Basin, at (relatively) low latitudes. Cores 4 and 5 (408-465 m subbottom) are referred to the MPl-4 biozone. Globorotalia puncticulata is consistently recorded in the lower part of this core, while its occurrence is scattered in Core 4. Several samples from Core 4 were examined to study the response of the foraminiferal faunas to sedimentary processes. The organogenic content is quite variable: for example, a sample processed from $147-149 \mathrm{~cm}$ in Section 1 produced an entirely biogenic sand-size fraction with planktonic foraminifers abundant, perfectly preserved, and well diversified. Other intervals investigated yielded relatively few, poorly preserved foraminifers, associated with abundant detrital minerals, glauconite, plant debris, etc. In other words, the faunal density (number of fossils per gram of sediment) seems to be strongly variable and is interpreted here as a consequence of dilution by the terrigenous input.
The five samples processed from Section 4, Core 4, where a number of erosional surfaces associated with turbiditic layers were observed, are quite different from one another. Epipelagic taxa are dominant at $20-22 \mathrm{~cm}$ and at $137-139 \mathrm{~cm}$; sorting by size (with an absence of small-sized taxa) is recorded at $134-136 \mathrm{~cm}$ and specimens reworked from the Cretaceous (Planomalina $\mathrm{sp}$.) were noted at $60-62 \mathrm{~cm}$. Abraded foraminiferal tests (benthic forms) displaced from shallower slopes are common in most sandy intervals, as for instance at 60 $62 \mathrm{~cm}$ and at $134-136 \mathrm{~cm}$.

\section{Early Pliocene}

Only the youngest biozone of the early Pliocene is represented at Site 371. MPl-3 was recorded in Samples 6, CC, 7, CC, and in the topmost part of Core 8 , Section 1. The concurrent range of Globorotalia margaritae (group) and of Globorotalia puncticulata makes this zone easily identifiable. The faunal assemblages are rich and diverse. The sand-size fraction of the sediment also contains a considerable terrigenous input.

\section{Miocene/Pliocene Boundary}

The early Pliocene sediments present in the topmost part of Core 8 are considered downhole contaminants. The abrupt contact between the massive evaporites and the hemipelagic sediment (see Figure 8 ) is considered a drilling artifact.

\section{Planktonic Foraminifers (Bizon)}

A Quaternary age was determined for Core 1 and part of Core 2. In Core 21 a warm-water planktonic foraminiferal assemblage is dominated by Globorotalia truncatulinoides (left coiling), Globorotalia inflata, Globorotalia anfracta, Globigerina praedigitata, Glohigerina aff. calida, Globigerinoides ruber, Globigerinoides tennellus, Hastigerina pelagica, Hastigerinella riedeli. Pink colored forms of Globigerinoides ruber occur in Core 1, Sections 1 and 2. Turborotalita humilis was recorded in Core 1, Sections 1 and 2, and Globorotalia hirsuta (right coiling) in Core 1, Section 2. Some specimens of the latter are recorded in the Quaternary of Alboran Sea cores and of the North Algerian Coast (Glacon et al., 1973). Since these species are generally absent in the present-day Mediterranean area, it is interesting to note the association of Atlantic forms in this area during the Quaternary.

The upper part of Core 2 containing a Quaternary temperate assemblage of planktonic foraminifers. In Sample 2-1, $120 \mathrm{~cm}$, some Globorotalia truncatulinoides were recorded and Globorotalia inflata is common. The lower part of Core 2 containing a temperate microfauna is of upper Pliocene age (Globorotalia inflata Zone 0).

Globigerinoides obliquus becomes extinct at approximately Sample 2-2, $33 \mathrm{~cm}$ while a cold interval occurs in Sample 2-2, $100 \mathrm{~cm}$, with Globorotalia pachyderma (sinistrally coiled), Globorotalia inflata, and Globigerina bulloides. Some Globorotalia hirsuta (left coiling) were also recorded. In Samples 2-3, $100 \mathrm{~cm}$ and 2, CC 
some Globorotalia aff. viola occurred (dextrally coiled). In Sample 2, CC, some Globorotalia truncatulinoides were recorded, but these could be a downhole contam. ination, as they are associated with several Globigeri. noides obliquus.

\section{Pliocene/Pleistocene Boundary}

This can be drawn at approximately Sample 2-2, 33 $\mathrm{cm}$. There is a suggestion that this may be a drilling artifact.

\section{Pliocene}

The upper part of Core 3 belongs to the upper Pliocene, Globorotalia inflata Zone, from Samples 3-1, $120 \mathrm{~cm}$ to $3-4,20 \mathrm{~cm}$. The lower part of Core 3 (from Samples 3-4, $100 \mathrm{~cm}$ to 3, CC) belongs to the Globig. erinoides obliquus extremus Zone. The first occurrence of Globorotalia inflata is in Sample 3-4, $20 \mathrm{~cm}$ while the last recorded occurrence of Globorotalia aemiliana is in Sample 3-4, $100 \mathrm{~cm}$. The boundary between the Globigerinoides obliquus extremus Zone and the Sphaeroidinellopsis subdehiscens Zone was unclear.

In Core 4, the planktonic foraminiferal assemblages are dominated by epipelagic species. Globigerinoides trilobus and Globigerinoides sacculifer are commonly associated with Globigerinoides obliquus and Globigeri. noides obliquus extremus. The first occurrence of Globorotalia aemiliana was recorded in Sample 4-4, $100 \mathrm{~cm}$. Some Sphaeroidinellopsis without external vitreous cortex were found in Core 4, Section 1. One Sphaeroidinellopsis cf. seminulina was found in Core 4, Section 4. In Core 4, Section 6, the last occurrence of Globoquadrina altispira was observed.

In Core 5, Globorotalia puncticulata is common, associated with frequent Sphaeroidinellopsis subdehis. cens and $S$. seminulina. This core belongs to the Sphaeroidinellopsis subdehiscens Zone. At present the boundary between the Sphaeroidinellopsis subdehiscens and the Globigerinoides obliquus extremus zones cannot be easily located. If this boundary is drawn in Core 4, it would presuppose an overlap of the Globorotalia aemiliana and Sphaeroidinellopsis zones, and this overlap is extremely rare in the Mediterranean area. On the other hand, reworking of foraminiferal species is well proven in these hemipelagic sediments.

The lower Pliocene sediments yielded very few planktonic foraminifers. In Samples 6, CC and 7, CC, Globorotalia margaritae and Globorotalia puncticulata are commonly associated with Globorotalia acostanen. sis (right coiling), Globigerinoides obliquus, Globigerinoides obliquus extremus, and Globigerinoides elongatus. This interval belongs to the Globorotalia margaritae evoluta Zone.

The upper part of Core 8 is probably a downhole contaminant. At Sample 8-1, $52 \mathrm{~cm}$, Globorotalia margaritae and Globorotalia margaritae primitiva were found with Globigerina nepenthes. This interval belongs to the Globorotalia margaritae Zone. In Samples 8-1, $74 \mathrm{~cm}, 8-2,108 \mathrm{~cm}, 8-3,53 \mathrm{~cm}$, and 8 , CC, a few specimens of reworked upper Cretaceous planktonic foraminifers (Hedbergella, Heterchelix) were recorded.
As some Globigerina nepenthes occur in Sample 8-1$52 \mathrm{~cm}$, there is no evidence of a major gap between the evaporites and the early Pliocene mudstones. Since we have at this site very few Sphaerodienllopsis and also the $\mathrm{CaCO}^{3}$ content decreases from Core 5 to Core 8 , it is possible that the Sphaeroidinellopsis acme is missing here due to ecological control.

Since the lowermost 16 meters of the Pliocene was not cored at this site, it is difficult to precisely determine the evaporites-Pilocene boundary. We have two possibilities: (1) There is a gap between the evaporites and the lower Pliocene with Globorotalia margaritae and Globigerina nepenthes. (2) The sedimentary succession was continuous from the evaporites through the sand layer to Pliocene mudstone.

It is impossible to choose between these two. The sequence at Site 121 drilled during Leg 13, is similar to that here. It has been suggested that the lowermost meters of the Pliocene could be present at Site 121 but were not cored (Montenat et al., 1975). Again both hypotheses are equally acceptable. It is the opinion of this writer that there is no evidence of a catastrophic change in environment at this boundary. The inferred sandy deposit might represent a transitional change from the Messinian salinity crisis to a Pliocene marine deposition.

\section{Benthic Foraminifers}

The benthic foraminifers in the samples from Site 371 are diagnostic lower epibathyal $(>500-700 \mathrm{~m})$ and upper mesobathyal $(>1000-1300 \mathrm{~m})$ genera and species include: Articulina tubulosa, Bulimina inflata, Cibicides robertsonianus, Eggerella bradyi, Eponides pusillus, E. umbonatus, Fissurina spp., Gyroidina orbicularis G. soldanii, Lagena spp., Pullenis bulloides, and Robertina translucens. Additional bathyal species were found which are typical of and abundant in the lower epibathyal and upper mesobathyal zones, but are not confined to these water depths. These species are: Cibicides pachyderma, Epistominella exigua, Sigmolina schlumbergeri, S. tenuis, and Sphaeroidina bulloides. The persistent nature of this fauna throughout the entire set of samples indicates that water depths from early Pliocene to Recent have remained deep. The ratio of planktonic to benthic foraminiferal tests is consistently high ( $>90 \%$ planktonic tests) and indicates water depths in excess of 1000 meters.

There is sporadic evidence of downslope faunal displacement throughout the entire Pliocene-Recent sequence. This evidence consists of worn specimens of Ammonia, Discorbis, Elphidium, Nonionella, and various Miliolidae.

The benthic foraminiferal fauna is not abundant in these samples, but is fairly well preserved.

\section{SEDIMENTATION RATES}

The sedimentation rates could not be calculated with accuracy at Site 371 because coring was discontinuous and scattered so that zonal boundaries related to the sequence of magnetic reversals, as in Ryan et al. (1974), could not be easily detected. In addition, the 
site location is atypical for the South Balearic Basin, being on a topographic high so making calculated rates somewhat anomalous. Moveover, it is not certain whether the Pliocene-Pleistocene boundary occurs in Core 2 or in the uncored interval between Cores 2 and 3.

The oldest Pliocene sediment recorded in Section 1 of Core 8 at 546 meters subbottom yielded a rich foraminiferal assemblage with Globorotalia margaritae evoluta giving an interpolated age of some 4 m.y., according to Cita.

If we were to hypothesize that the entire Pliocene and Pleistocene succession is present at Site 371, without any significant time-gap, the resulting average sedimentation rate would be about $10.5 \mathrm{~cm} / 10^{3} \mathrm{yr}$. However, as discussed in the previous section, it is likely that one or more hiatuses are present in the late Pliocene. Following this line of reasoning, the sedimentation rate would be considerably higher, of some 13.6 $\mathrm{cm} / 10^{3} \mathrm{yr}$ or more.

Figure 13 shows a plot of relative zonal boundary depths as assigned by the shipboard paleontologists (see Figure 12). Three points are placed with some general agreement: (1) the Pliocene-Pleistocene boundary at around -200 meters (Müller and Bizon). (2) the MPl-3/MPl-4 (early-late Pliocene) boundary at about -490 meters (Bizon and Cita). (3) the Miocene (Messinian) to Pliocene (MPl-2 or MPl-3) contact at -539 meters (see also operations report, this chapter).

Assuming a $1 \mathrm{~m} . \mathrm{y}$. hiatus at the base of the Pliocene and using these points the early Pliocene sedimentation rate would have been about $7.0 \mathrm{~cm} / 10^{3} \mathrm{yr}$ while that for the late Pliocene and Quaternary would have been $19.3 \mathrm{~cm} / 10^{3} \mathrm{yr}$ and $11.1 \mathrm{~cm} / 10^{3} \mathrm{yr}$, respectively. From seismic profiling (see next section) the Plio-Quaternary sequence in the basin to the west of the site appears to be about 850 meters thick. This would suggest that sedimentation rates in excess of $16.3 \mathrm{~cm} / 10^{3} \mathrm{yr}$ are typical of the South Balearic Basin. The figures compare with a Plio/Pleistocene sedimentation rate of about $200 \mathrm{~m} / \mathrm{m}$.y. calculated at Site 121 in the Alboran Sea, which has a similar setting. For further discussion of the possible implications of these accumulation rates see Cita et al. (this volume).

\section{CORRELATION OF SEISMIC REFLECTION PROFILES WITH DRILLING RESULTS}

The correlation of seismic reflection profiles with drilling results at Site 371 is by reference to the profile IFP J-103 and the Glomar Challenger record of site approach. It is apparent that the combination of these two profiles is not simple because of differences in source and recording systems used.

In this area the penetration of the Glomar Challenger profile was limited by horizon $\mathrm{M}$, the top of the Messinian evaporites. The target, a basement high with "pinch-out" of the thick salt layer around it, was defined by the IFP profile, which also provided information from below the evaporites. Comparison of the profiles is tentative because of the great difference in scale used: for the IFP profile the vertical exaggeration

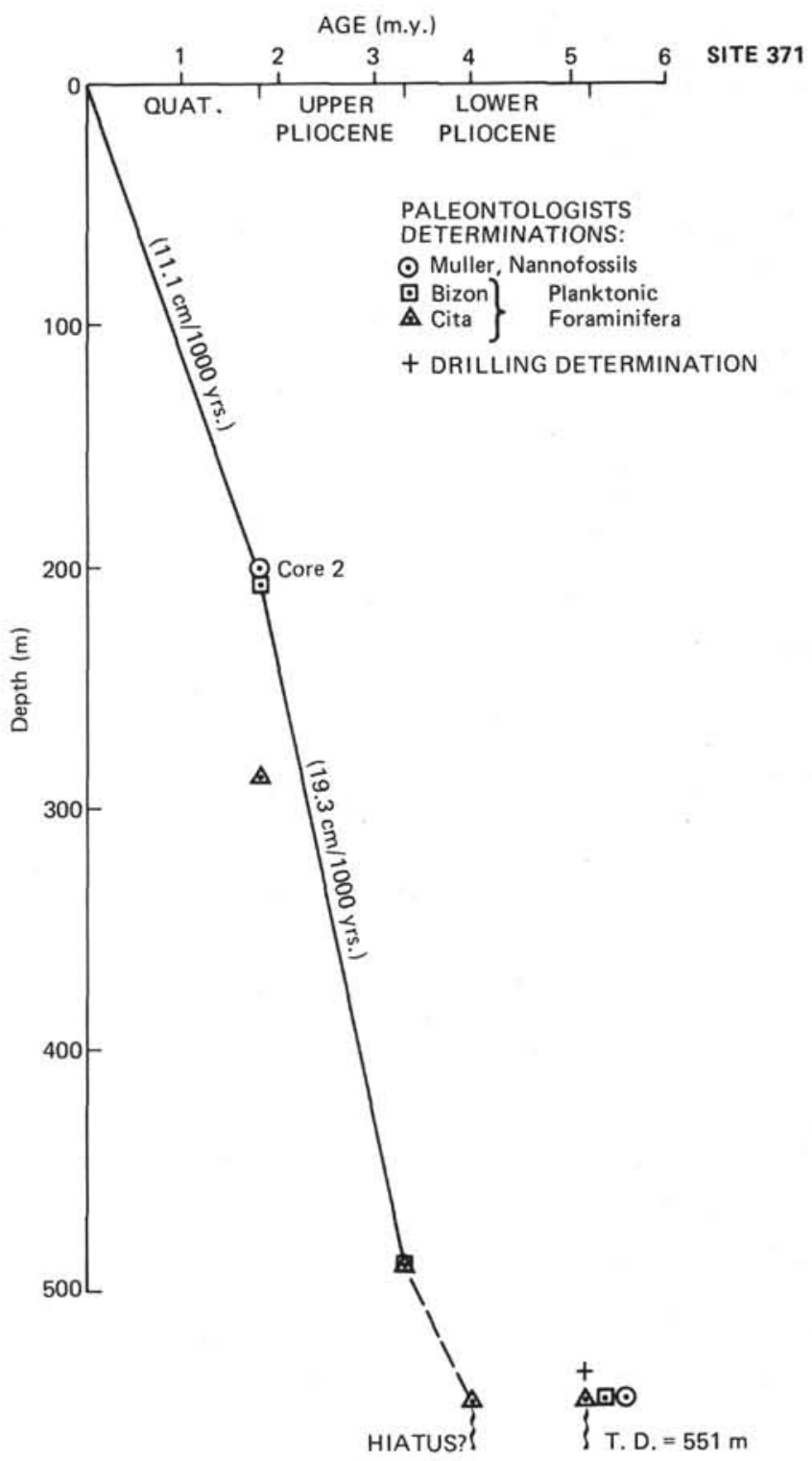

Figure 13. Sedimentation rates at Site 371 .

in scale is about 2; for the Glomar Challenger profile the exaggeration is about 8 . This may be a general cause of problems when the Glomar Challenger profiling system is used to approach a site in complicated areas, such as the Mediterranean, with a multichannel reflection profile as reference.

On the Glomar Challenger profile, two units can be recognized in the Pliocene-Quaternary sequence above the M-reflector: an upper unit with no reflectors (Figure 14).

In the area west of the site, the upper unit is about 300 meters thick, the lower one about 400 meters. On the IFP profile, a third relector is visible at about 500 meters subbottom. From the velocity-depth curve computed from the multichannel seismic data, the total thickness of the Plio-Quaternary sequence is shown to be about 850 meters, with the two main units, respectively, 300 and 550 meters thick. On top of the target structure, as shown on the Glomar Challenger profile, these two units can be recognized, but with reduced 


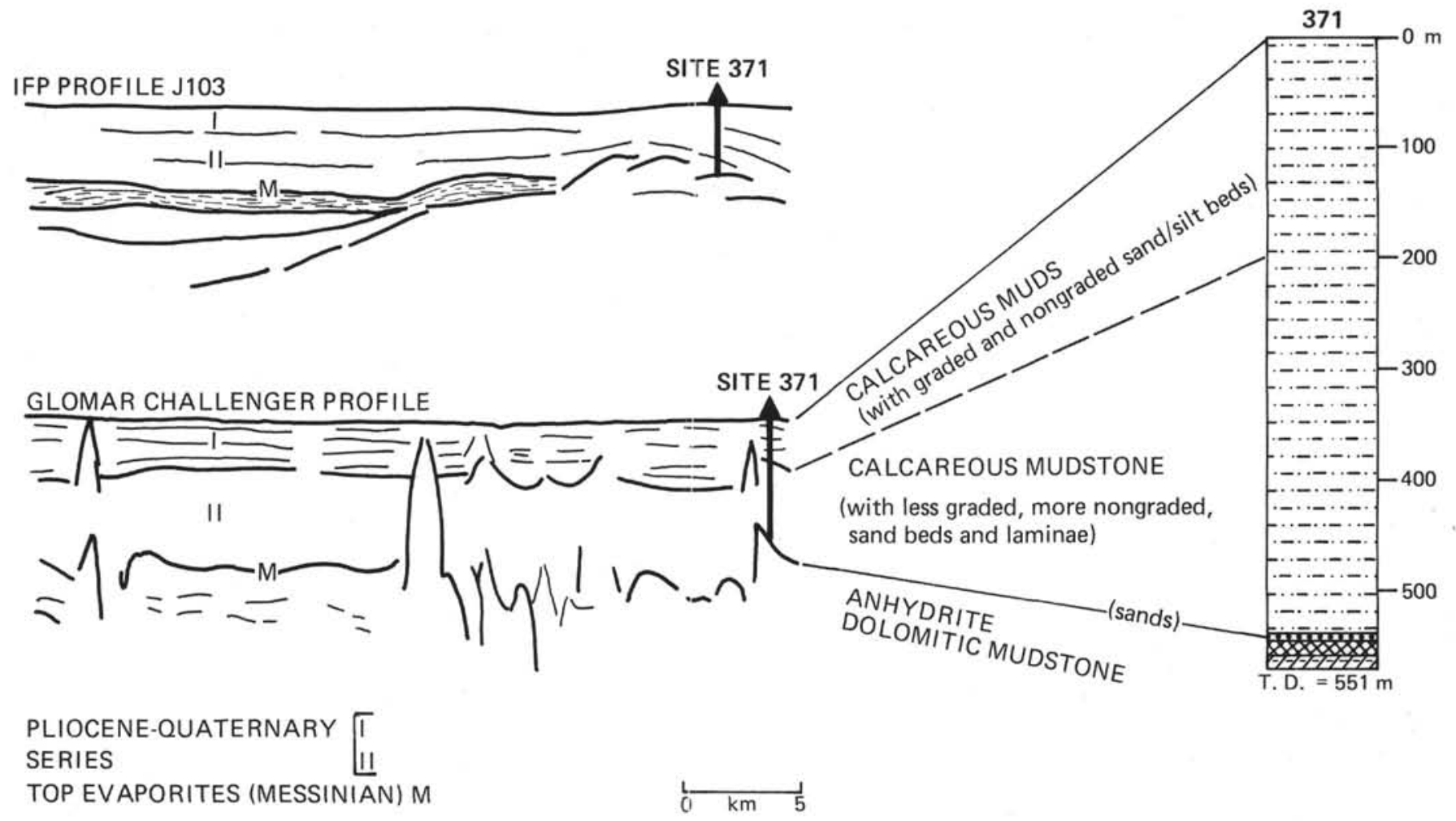

Figure 14. Correlation of seismic reflection profiles with drilling results at Site 371.

thickness, respectively, about 150-200 meters and 230280 meters.

From the few cores recovered at Site 371, it appears that the lithology is almost constant through most of the hole. The only significant changes are a downhole increase in the frequency of sandy intercalations together with the lithification of the calcareous muds to mudstones. The sandy layers are less numerous in the upper part, but there is a greater frequency of graded bedding. The sharp contacts of these graded beds with the underlying unconsolidated muds may explain the numerous reflections present in the upper unit of the Plio-Quaternary sequence.

On the Glomar Challenger profile the target-reflector appears similar to the M-reflector in the surrounding areas. However, it can be seen on the IFP profiles that: the structure differs from surrounding diapir structures and that the salts pinch out on the flanks of the structure. It was nevertheless uncertain whether the Plio-Quaternary sequence rests directly on a "basement" on top of the structure or whether a thin veneer of the evaporite sequence is still present there overlying the basement. The drilling showed that evaporites were still present at a distance of $2.5 \mathrm{~km}$ from the top of the structure.

\section{SUMMARY AND CONCLUSIONS}

The site was located on the southern edge of the Balearic Abyssal Plain at $37^{\circ} 35.88^{\prime} \mathrm{N}$ and $5^{\circ} 14.55^{\prime}$ in 2816 meters of water (Figure 1). The hole penetrated 551 meters of sediment, and into the Messinian evaporite. It had to be abandoned in accordance with a ruling by the JOIDES Safety Panel that we should terminate drilling at this location after the first evaporite core .

\section{Distribution of Evaporite on Basement High}

The drill site was located on the flank of a positive structural feature as shown by the IFP multichannel seismic profiles (Figure 6). In contrast to the numerous salt diapirs, this structure has a positive magnetic anomaly (Figure 3 ), and the reflection pattern shows that it is a basement high. A thick Plio-Quaternary (up to $1 \mathrm{~km}$ ) and a very thick evaporite series (up to about $2 \mathrm{~km}$ ) normally underlie the Balearic Abyssal Plain but these series are thin above this "basement-high" and may be absent altogether at its crest. The primary objective of our drilling was to determine if a hole on this high, previously suggested for future deep penetration, could reach basement without having to drill through the evaporite. Site 371 was located at a position about $2.5 \mathrm{~km}$ east of the basement crest. It was found that the acoustic basement at the site underlies an evaporite unit. Whether the basement subcrops under the Plio-Quaternary at the crestal position remains unknown. The seismic profiles, reinterpreted on the basis of the information gathered from this drill hole, suggest that the evaporite cover may extend also to the crestal position. We made no attempt to test this high-risk objective.

\section{Neogene History}

Our second objective was to obtain information on the Neogene history in this region. 
The hole penetrated a relatively thick Plio-Quaternary sequence and was terminated in gypsiferous dolomitic mudstone: Two major stratigraphic units have been recognized:

\section{Unit I. Plio-Quaternary Sequence}

The sequence consists mainly of calcareous muds which are sufficiently indurated below 410 meters depth to be classified as mudstones. Intercalated with the mudstones are graded and nongraded sandy beds and laminae.

Biogenic and detrital $\mathrm{CaCO}_{3}$ comprise only $25 \%$ $30 \%$ of the bulk. The muds on this abyssal hill are thus more terrigenous than average hemipelagic sediments (cf. $30 \%-65 \% \mathrm{CaCO}_{3}$ at Plio-Quaternary at Site 124 on the Balearic Rise, and at Site 134 under the abyssal plain just west of the Sardinia slope). The high rate of sedimentation $\left(\sim 14 \mathrm{~cm} / 10^{3} \mathrm{yr}\right)$ can be interpreted mainly in terms of detrital influx (80\%-90\%); biogenic production here is probably not higher than usual. Intercalated in the muds are sandy laminae and beds which constitute less than $10 \%$ of the section. The sand-size component of the sandy layers decreases from $80 \%$ at the base (Core 5, Pliocene) to $23 \%$ at the top of the sequence (Core 1, late Quaternary). The variation in sand content is atypical for the Mediterranean Plio-Quaternary of the Mediterranean Deep Basins which usually has a lower terrigenous input in the earlier Pliocene (Cita et al., this volume). This somewhat abnormal pattern may simply reflect the gradual burial of a local sand source.

Hemipelagic deposition seems to have taken place on a knoll which has stood slightly above the surrounding abyssal plain since the early Pliocene. At times, distal deposits of turbidity currents may have reached this location to deposit the graded sand. Both types of deposit were intermittently reworked, probably by contour currents. Unrestricted basin circulation is further indicated by active bioturbation.

A paleobathymetric analysis of the benthic foraminifers found at this site reveals that the depositional environment here was at least as deep as the mesobathyal $(>1200 \mathrm{~m})$ zone from the early Pliocene (Zanclean) to the Holocene.

Although the lowermost 10 meters of the Pliocene was not cored, we suppose that the earliest Pliocene is absent here. Drilling during the Leg 13 cruise has indicated that the earliest Pliocene sediments in Mediterranean deep-sea sections tend to be absent on basement highs. The hiatus here may span half to one million years. (Pliocene zones MPl-1 and possibly all of MPI-2 are missing). It has been suggested that the earliest Pliocene was a time of very intense current activity when hemipelagic sediments on abyssal hills tended to be swept away by bottom-current activity (Ryan, Hsü , et al., 1973).

\section{Unit II. Mediterranean Evaporite}

We cored only the topmost 5 meters of the evaporite formation which underlies the Pliocene unconformably. Seismic reflection in the South Balearic Basin shows that the salt layer pinches out around the basement structure but that the upper evaporitic sequence extends considerably farther (Biju-Duval et al., 1974). Since at this site the evaporite is located on a topographic high, we can assume that it is a part of the upper evajporitic sequence. It is interesting to note from the drilling records that the evaporite is probably topped by a 6-meter-thick layer of sand. This horizon might be an equivalent of the "Arenazzolo" deposit which lies above the Solfifera series in Sicily. (See Ryan, Hsü, et al., 1973, p. 1217).

The cored interval includes an upper anhydrite section with thin dolomitic mudstone interlayers followed downwards by brown dolomitic mudstone in the lower part of the hole. The association of sedimentary structures indicates that the anhydrite (dolomitic mudstone cycles were deposited "subaerially." Stromatolite is one form of sedimentary structure present, although identification of algal filaments is necessary to positively define the environments. Another, nodular anhydrite, is believed to have been formed diagenetically in a sabkha environment. The dolomitic mudstone at the base of the hole is probably the result of deposition in a shallow subaqueous environment such as near a coastal sabkha, or supersaline lake or near-shore laguna. It is barren of fossils and is probably of terrestrial origin.

\section{Origin of the Evaporites}

The evaporite sequence underlying the M-reflector yielded no fossils diagnostic of age, but is recognized as the upper Miocene Mediterranean evaporite on the basis of correlations by seismic profiling. The presence of nodular anhydrite, stromatolitic carbonates, and unfossiliferous dolomitic mudstones in this sequence all point to the interpretation that this site was subaerially exposed or submerged under very shallow waters during the late Miocene. The change from evaporite sedimentation to hemipelagic marl deposition in the Pliocene seems, from drilling characteristics, to be rather abrupt. This suggests that the site was flooded by an open sea shortly after the evaporite deposition; the water depth here reached at least 1000 meters prior to the deposition of the oldest Pliocene ooze cored at the site (MPl-3, Cita: MPl-2, Bizon). Paleoecological analyses found no recognizable depth-changes since MPl-3 time. The interpretation that a shallow salt pan was flooded by a Pliocene deep sea is consistent with our conclusions as to the genesis of the Mediterranean evaporites, as presented in the synthesis chapter (Hsü et al., this volume).

\section{REFERENCES}

Auzende J. M., Bonnin J., and Olivet, J. L., 1973. The origin of the Western Mediterranean Basin: J. Geol. Soc. London, v. 129 , p. 607-620.

Bayer R., Le Mouec J. L., and Le Pichon, X., 1973. Magnetic Anomaly pattern in the Western Mediterranean: Earth Planet. Sci. Lett., v. 19, p. 168-176.

Biju-Duval, B., Letouzey, J., Montadert, L., Courrier, P., Mugniot, J.F., and Sancho, J., 1974. Geology of the 
Mediterranean Sea Basins. In Burk, C. and Drake, C. (Eds.), The geology of continental margins: New York (Springer Verlag).

Cita M. B., Chierci M. A., Ciampo G., Moncharmont M. D'Onofrio S., Ryan W. B. F., and Scorzielo R., 1972. The Quaternary record in the Tyrrhenian and Ionian Basins of the Mediterranean. In Ryan, W. B. F., Hsü, K. J., et al., Initial Reports of the Deep Sea Drilling Project, Volume 13; Washington (U.S. Government Printing Office), p. 1263-1339.

Fahlquist, D. A. and Hersey, J. B., 1969. Seismic refraction measurements in the Western Mediterranean Sea: Inst. Oceanogr. Monaco Bull. 67, 1386, p. 1.

Glaçon, et al., 1973. Presence des foraminiferes: Globorotalia crossula (Cushman and Stewart) et Globorotalia hirsuita (d'Orbiging) en mer Méditerranée: Riv. Esp. Micropal., v.3, p. 373-401.

Mauffret, A., Fael, J. P., Montadert, L., Sancho, J., and Winnock, E., 1973. Northwestern Mediterranean sedimentary basins from seismic reflection profile: Am. Assoc Petrol. Geol. Bull., v. 57, p. 2245-2262.
McIntyre, A., Bè., A. W. H., and Preikstas R., 1967. Coccoliths and the Plio-Pleistocene Boundary: Progress in oceanography, v. 4, p. 3-25.

Montenat, C., Bizon, G., and Bizon, J.J., 1975. Remarques sur le Néogène du forage JOIDES. 121 en Mer d'Alboran (Méditerranée occidentale): B.S.G.F., v. 17, p. 45-51.

Ryan, W. B. F., Hsü, K. J., et al., 1973. Initial Reports of the Deep Sea Drilling Project; Volume 13: Washington (U.S. Government Printing Office.)

Ryan, W. B. F., Cita, M. B., Dreyfus, Rawson M., Burckle, L. H., and Saito, T., 1974. A Paleomagnetic assignment of Neogene stage boundaries and the development of isochronous datum planes between the Mediterranean, the Pacific, and Indian oceans in order to investigate the response of the World Ocean to the Mediterranean "Salinity Crisis"; Riv. Ital. Pal. Strat., v. 80 p. 631-688.

Stradner, H., 1973. Catalogue of calcareous Nannoplankton from sediments of Neogene age in the North Atlantic and Mediterranean Sea. In Ryan, W. B. F., Hsü, K. J., et al., Initial Reports of the Deep Sea Drilling Project, Volume 13: Washington (U.S. Government Printing Office), p. 1137-1119. 

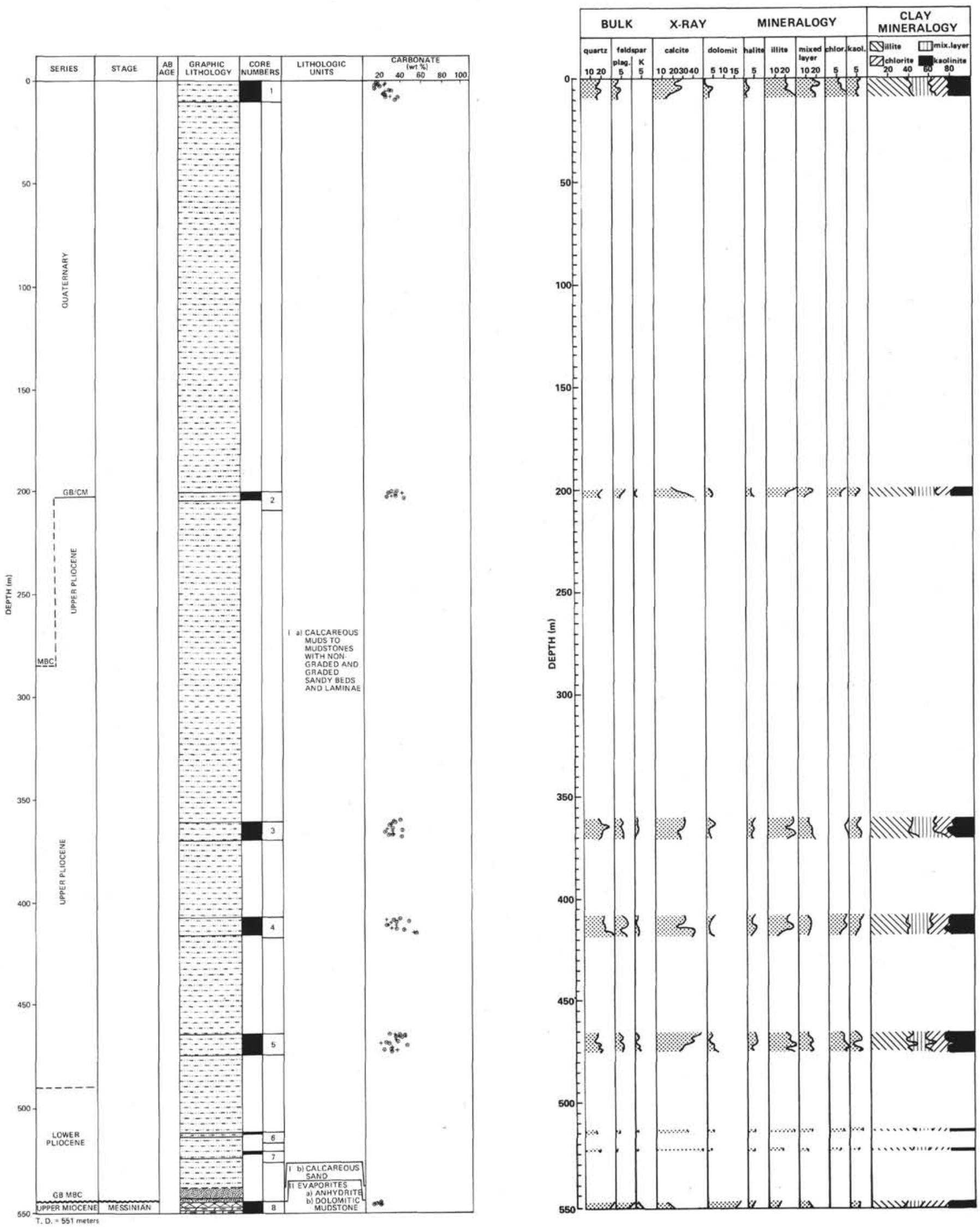

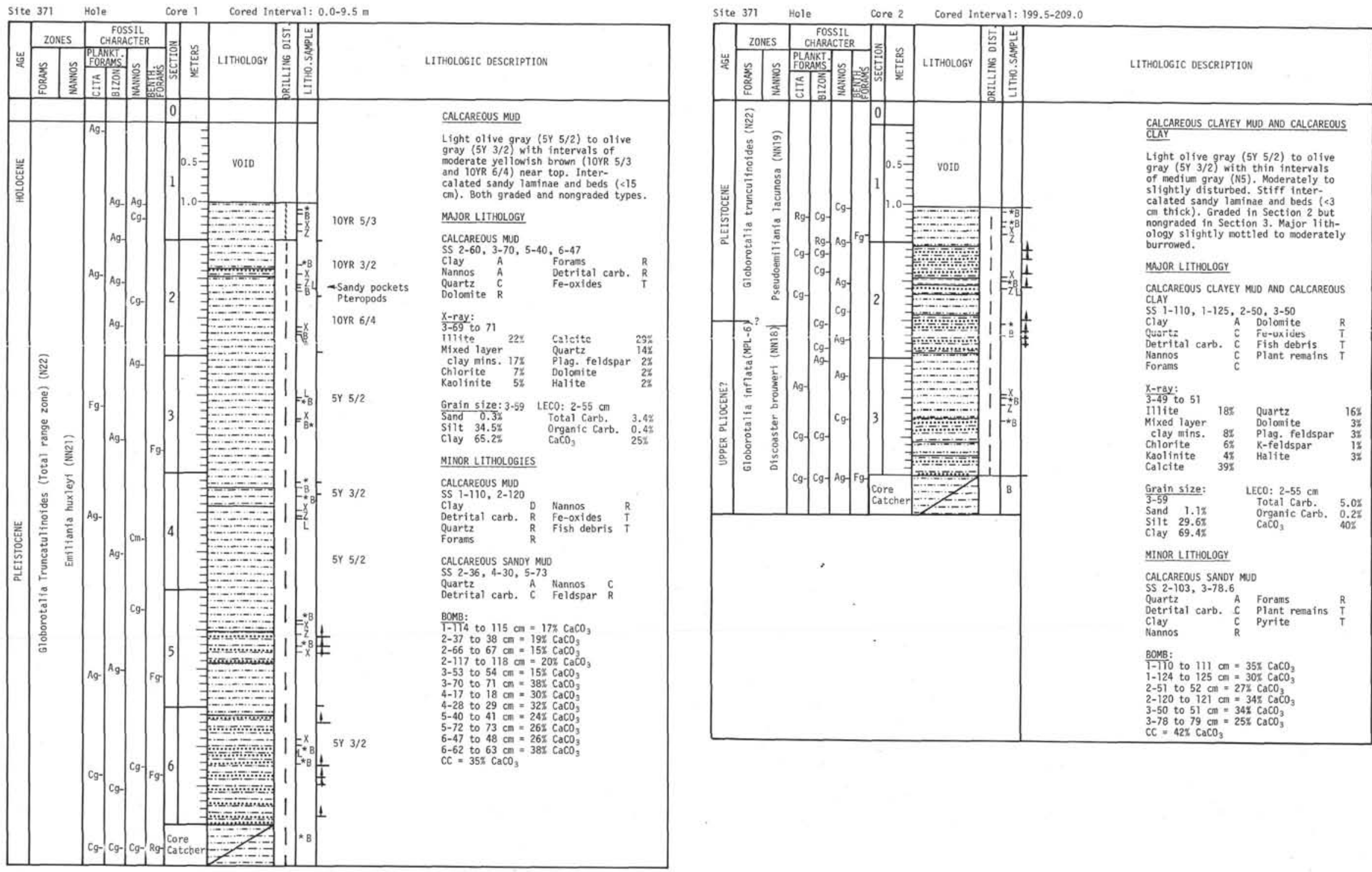

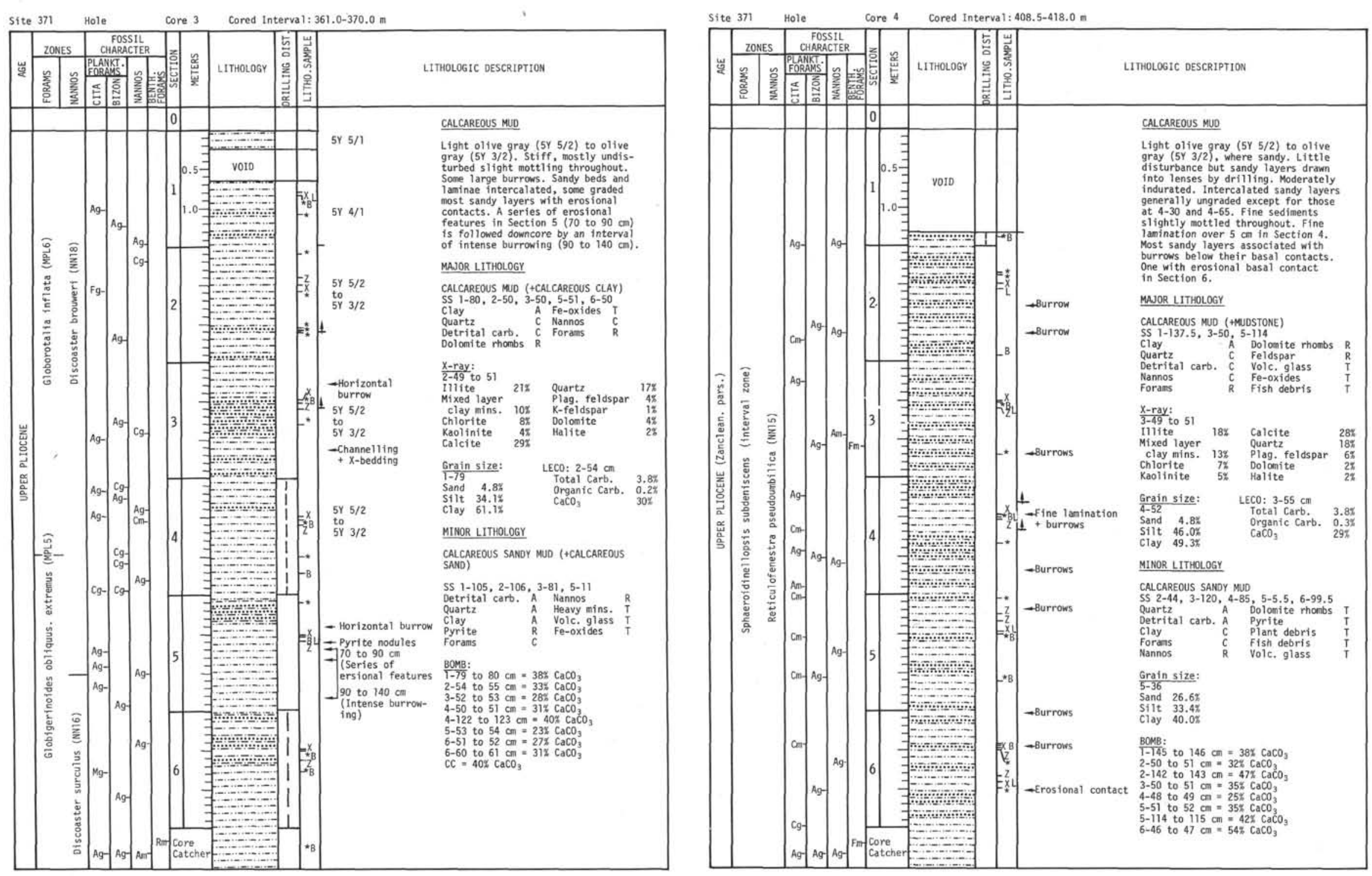

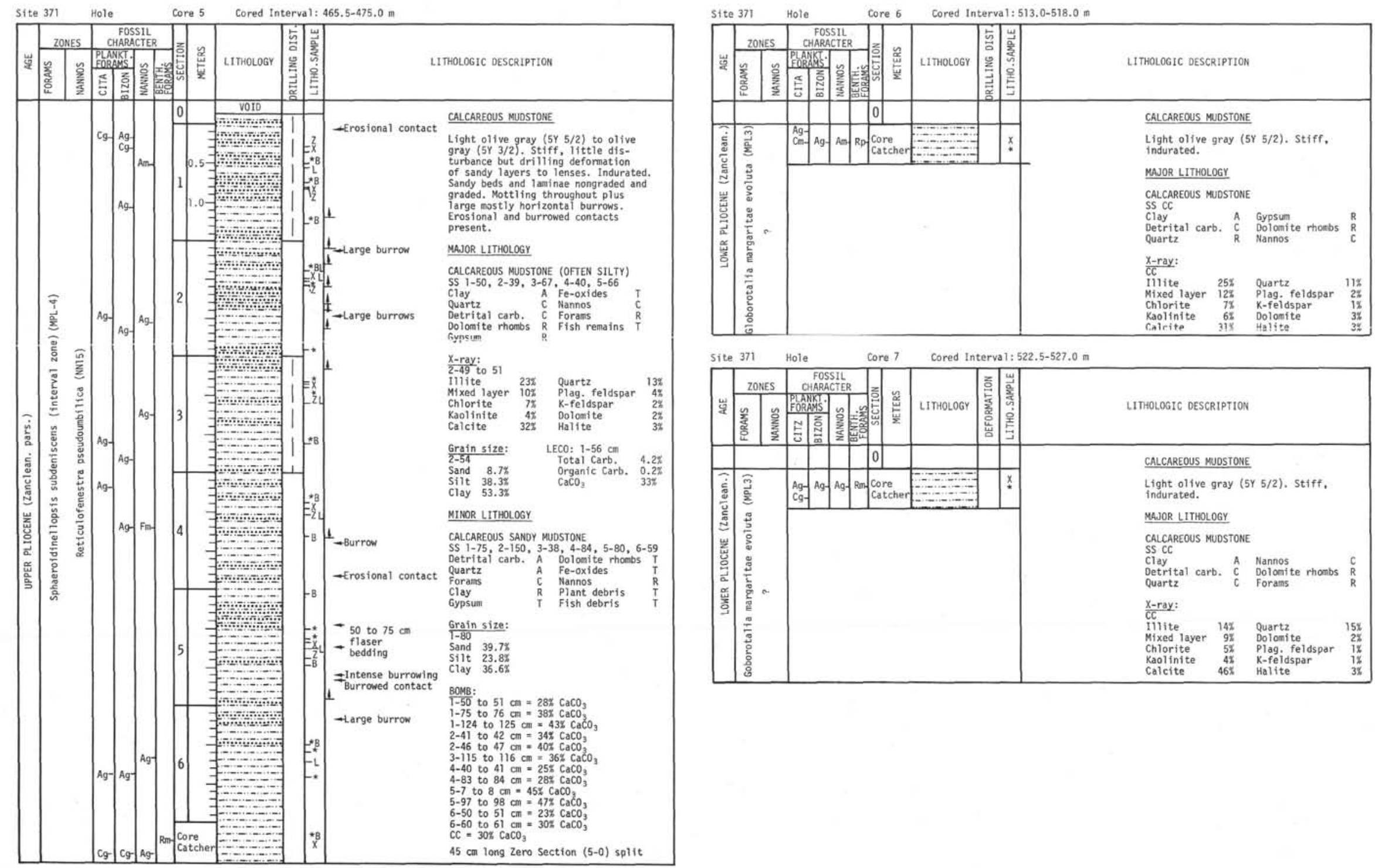

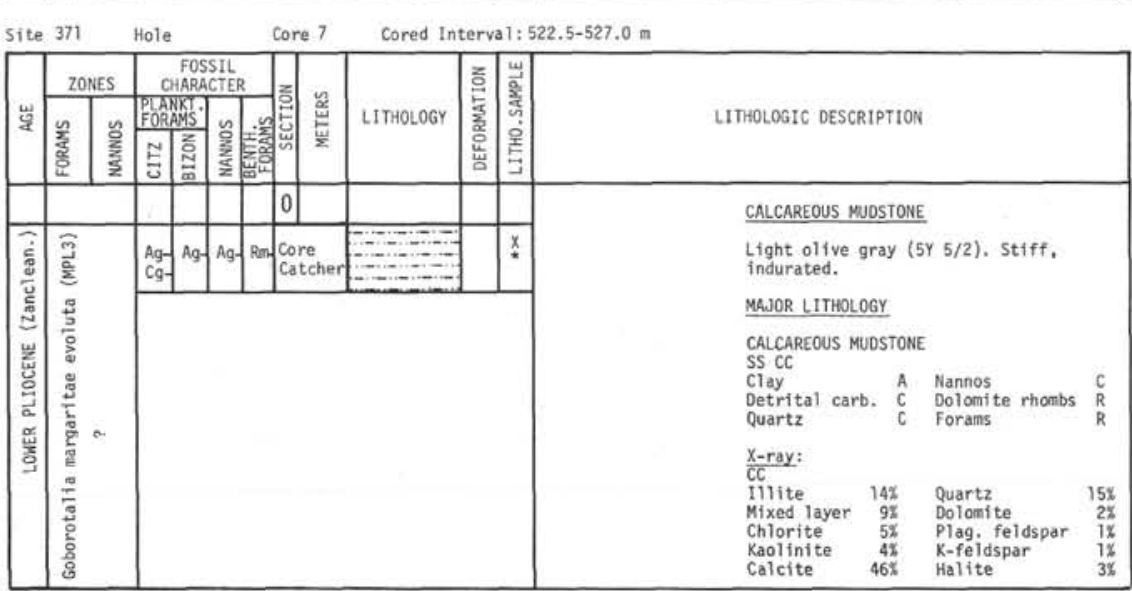




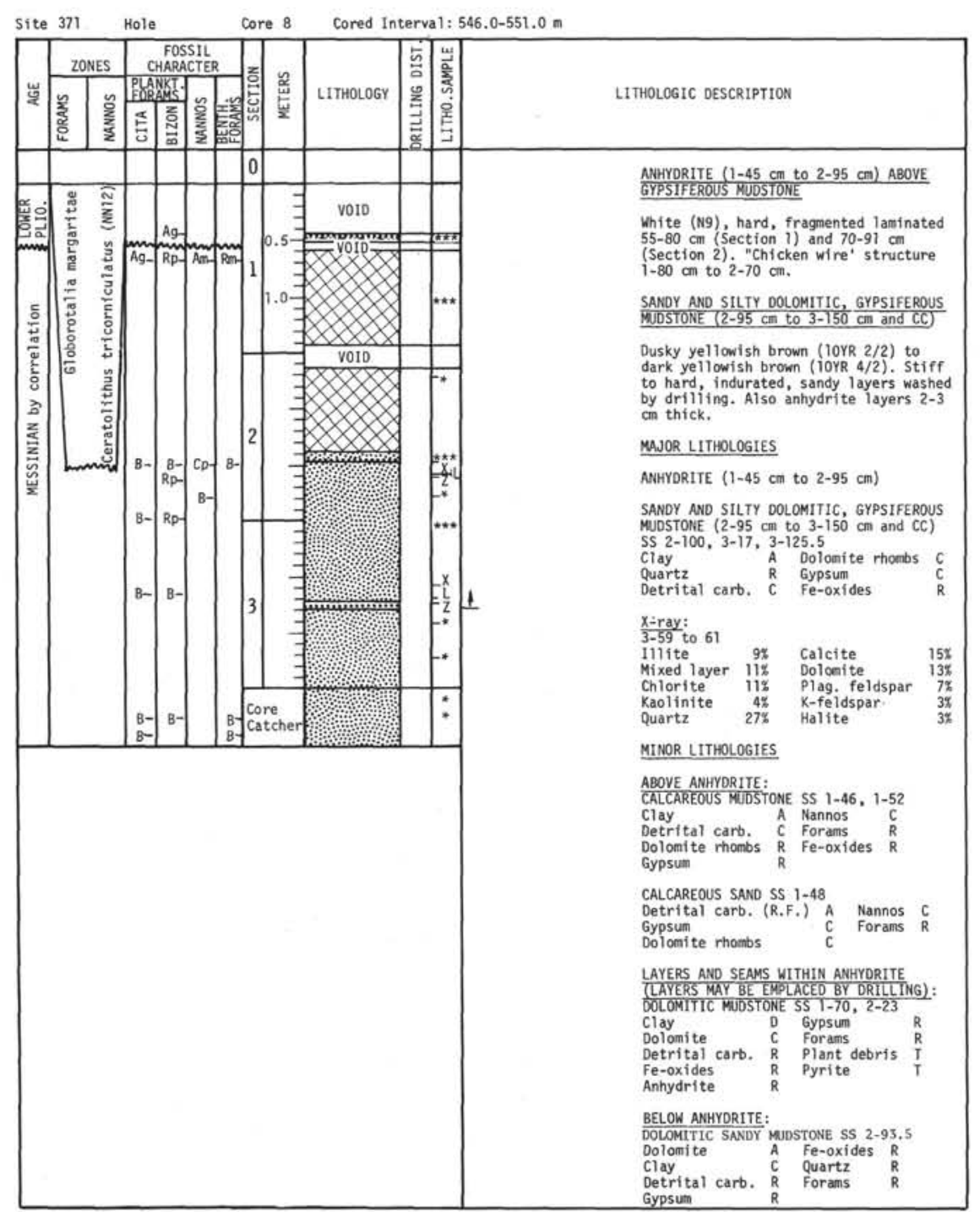




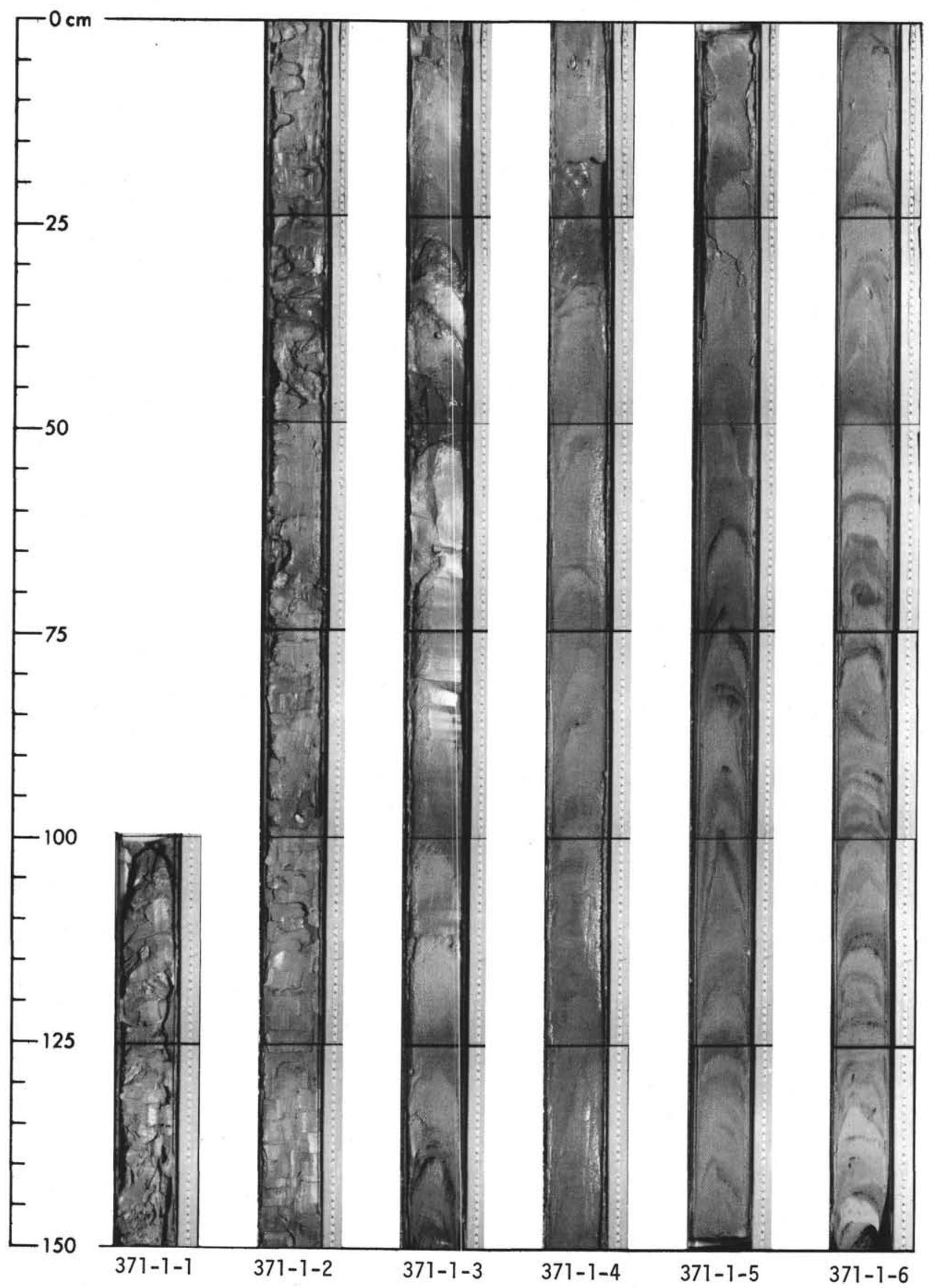




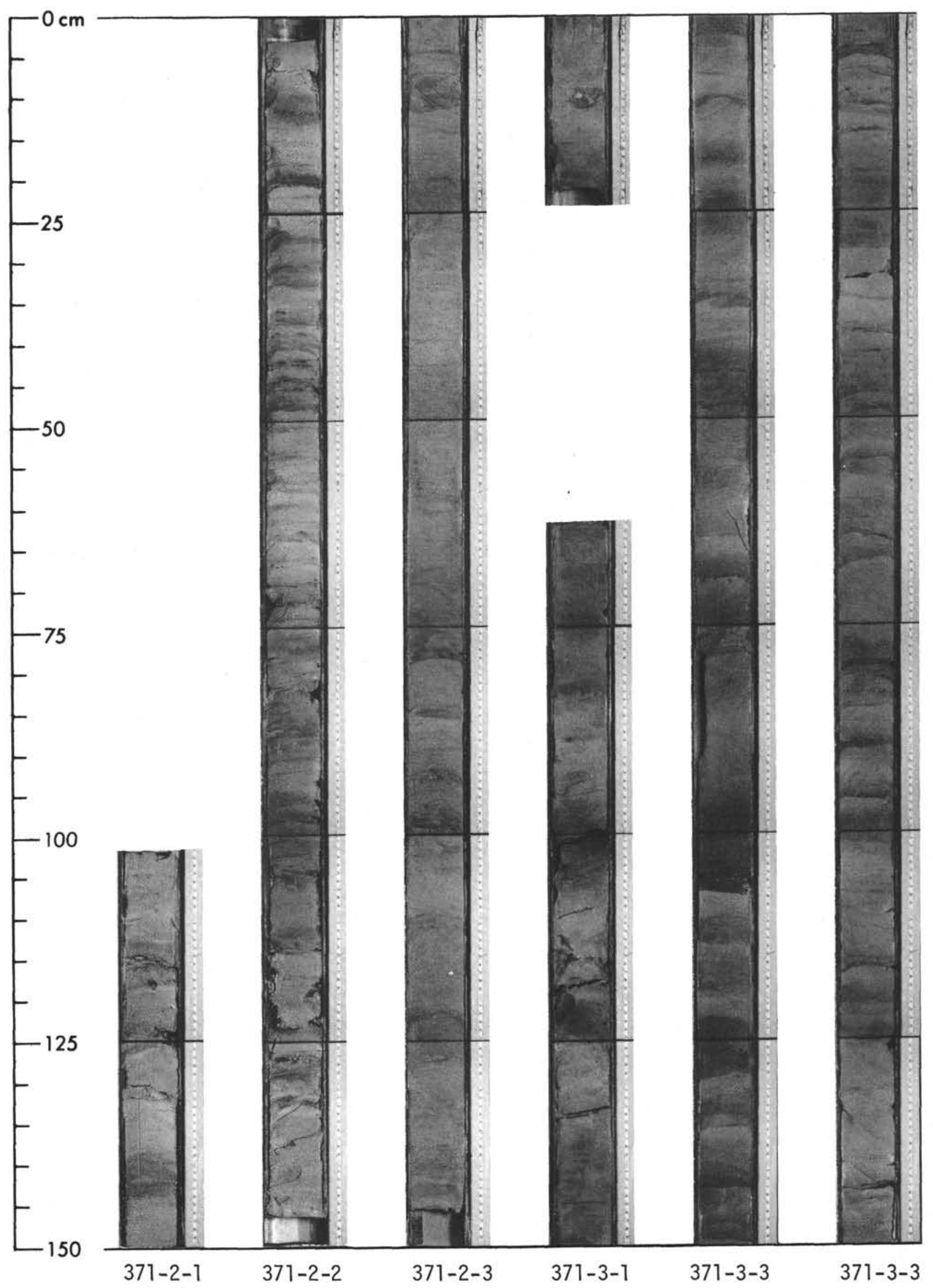




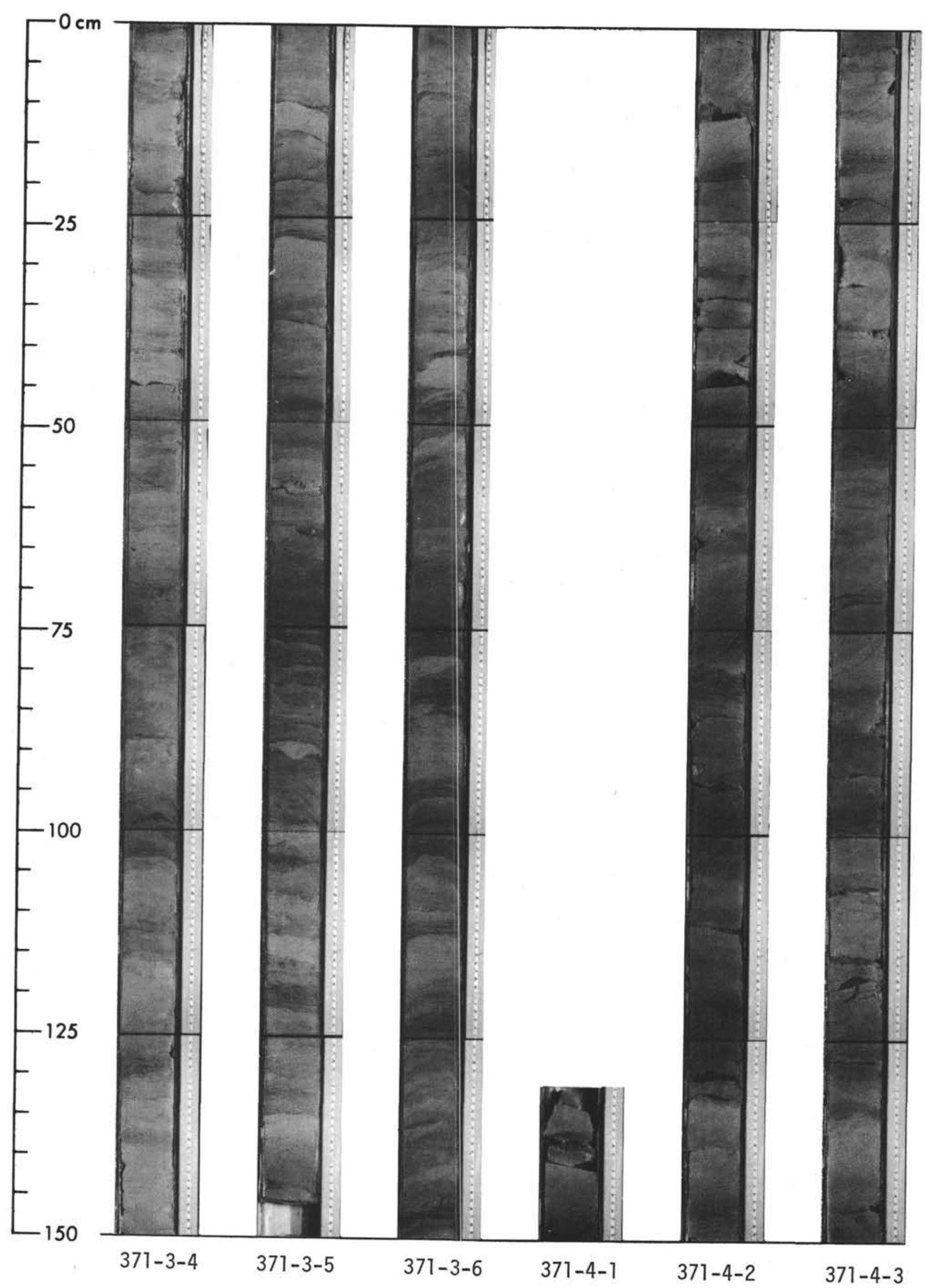




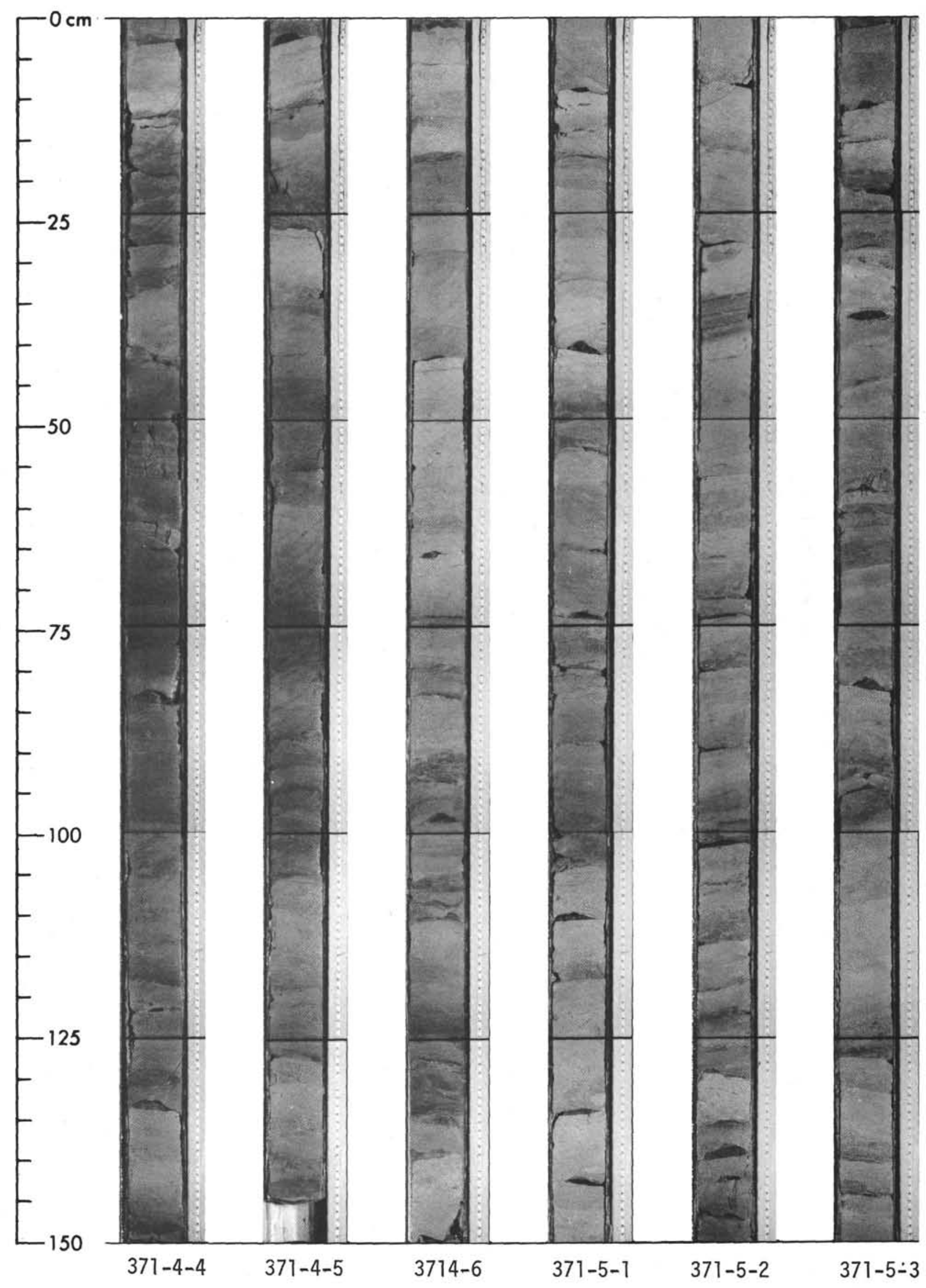


SITE 371: SOUTH BALEARIC BASIN

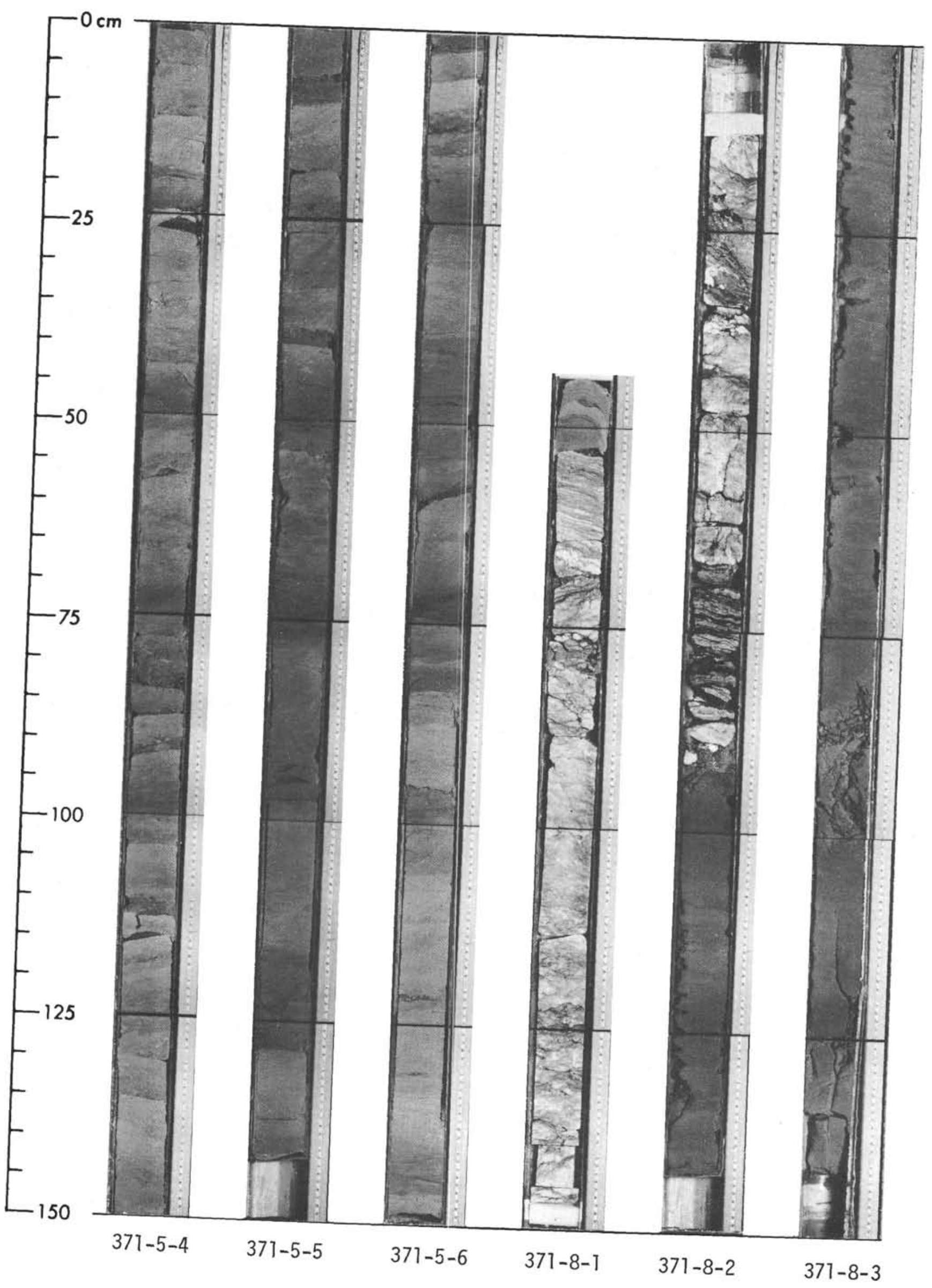

